\title{
Spor İşletmelerinde Müşteri Memnuniyetinin Bazı Değişkenlere Göre İncelenmesi ${ }^{1}$
}

\author{
DOI: 10.26466/opus.899522 \\ $*$ \\ Sema Uslu * - Mehmet Yıldırım** \\ * Bilim Uzmanı, Sorgun Halk Eğitim Merkezi, Yozgat/Türkiye \\ E-Posta: semauslu@hotmail.com \\ ORCID: 0000-0002-4634-7662 \\ ** Doç. Dr. Yozgat Bozok Üniversitesi, Spor Bilimleri Fakültesi, Yozgat, Türkiye \\ E-Posta: mehmet2682@hotmail.com \\ ORCID: $\underline{0000-0002-9707-6540}$
}

Öz

Bu araştırmanın amacl; spor işletmelerinde müşteri memnuniyetinin bazı değişkenlere göre incelenmesidir. Araştırmaya Yozgat Il'inde bulunan spor işletmeleri arasından kolayda örnekleme tekniği ile seçilen, 2019-2020 kışs sezonunda 1 Aralık-28 Şubat tarihleri arasında spor işletmelerinde müşteri olan 340 kadın, 260 erkek toplam 600 müşteri gönüllü olarak katılmıştır. Yozgat ilinin sunduğu koşullar itibariyle spor işletmeleri büyüklükleri, sundukları programlar (fitness, plates, zumba, taekwondo, box, step aerobik, voleybol, basketbol, futbol vb.) ve üye sayılarn dikkate alınarak seçilmiştir. Araştırmada veri toplama aracı olarak katılımcıların kişisel bilgilerini toplamak amactyla araştırmacı tarafından hazırlanan "Demografik Bilgi Formu (DBF)" ile birlikte, Sevilmiş (2015) tarafından geliştirilen "Spor İşletmelerinde Müşteri Memnuniyeti Ölçeği (SIMMÖ)" kullanılmıştır.Araştırmada elde edilen veriler SPSS 20 programına aktarılmıştır. Verilerin analizinde öncelikle katılımcıların kişisel özelliklerini belirlemeye ilişkin betimleyici frekans ( $n$ ), yüzde (\%), aritmetik ortalama ( $x$ ) ve standart sapma (ss) kullanılmıştır. Çalışmanın güvenirlik değerleri düzeyinin saptanmasında ise iç tutarlılık için "Cronbach alpha katsayısı" yöntemi uygulanmıştır. Araştırmada veri setinin basıklık ve çarpıklık değerleri incelenmiş ve verilerin normal dağıllım sergilediği tespit edilerek, istatistiki analizlerinde parametrik testler (T-Testi, Anova) kullanılmıştır. Araştırmanın sonucunda, memnuniyet ölçeğinden algıladıkları puanların müşterilerin cinsiyet, yaş, aylık gelir düzeyi, daha önce bir spor merkezinden yararlanma durumu, şu an yararlanmakta olduğunuz spor merkezi, üyelik süresi ve yararlanılan spor tesisinin türü değişkenlerine göre istatistiksel olarak anlaml farklar tespit edilmiştir. Spor işletmeleri müşterilerinin memnuniyet düzeyleri için medeni durum değişkenine göre istatistiksel olarak anlaml fark tespit edilememiştir. Bununla birlikte genel olarak spor işletmeleri müşterilerinin memnuniyet düzeylerinin yüksek sevide olduğu tespit edilmiştir.

Anahtar Kelimeler: Spor işletmeleri, müşteri, memnuniyet

\footnotetext{
${ }^{I}$ Bu araştırma; Yozgat Bozok Üniversitesi, Lisansüstü Eğitim Enstitüsü, Beden Eğitimi ve Spor Anabilim dalında Doç. Dr. Mehmet YILDIRIM danışmanlığında yürütülen Sema Uslu'nun 2021 yılında tamamladı̆̆ı "Spor Işsletmelerinde Müşteri Memnuniyetinin Bazı Değişkenlere Göre İncelenmesi" adlı yüksek lisans tezinden üretilmiştir.
} 


\title{
Investigation of Customer Satisfaction in Sports Business According to Some Variables
}

\begin{abstract}
The purpose of this research; It is the examination of customer satisfaction in sports businesses according to some variables. A total of 600 customers, 340 women and 260 men, who were customers in sports businesses between December 1 and February 28, voluntarily participated in the study, which were selected by the convenience sampling technique among the sports businesses in Yozgat Province. According to the conditions offered by the city of Yozgat, sports businesses have been selected by taking into account their size, the programs they offer (fitness, plates, zumba, taekwondo, box, step aerobics, volleyball, basketball, football, etc.) and the number of members. The "Demographic Information Form $(D B F)^{\prime \prime}$ prepared by the researcher and the "Customer Satisfaction Scale in Sports Businesses (SIMMÖ)" developed by Sevmiş (2015) were used as data collection tools in the study. The data obtained in the research were transferred to the SPSS 20 program. In the analysis of the data, descriptive frequency $(n)$, percentage $(\%)$, arithmetic mean $(x)$ and standard deviation $(s d)$ were used to determine the personal characteristics of the participants. The "Cronbach alpha coefficient" method was used for internal consistency in determining the level of reliability values of the study. In the study, kurtosis and skewness values of the data set were examined and it was determined that the data showed a normal distribution, and parametric tests (T-Test, Anova) were used in statistical analysis. As a result of the study, statistically significant differences were determined in the scores perceived from the satisfaction scale according to the variables of gender, age, monthly income level of the customers, the status of using a sports center before, the sports center you are currently using, the duration of membership and the type of sports facility used. A statistically significant difference was not found for the satisfaction levels of the customers of the sports businesses according to the marital status variable. In addition, it has been determined that the satisfaction levels of the customers of sports businesses are generally at a high level.
\end{abstract}

Keywords: Sports businesses, customer, satisfaction. 


\section{Giriş}

Globalleşen günümüz dünyasında teknolojinin her geçen gün hızla ilerlemesiyle insan gücünün yerini hızla makineleşmenin alması ve artan rekabet koşullarıyla birlikte yoğun iş ve günlük yaşantının temposu da artmakta ve buna bağlı olarak hareket azlığı ile birçok sağlık sorunlarını da beraberinde getirdiği düşünülmektedir. Dünyada spor sektörü, geçmişten günümüze sürekli gelişim göstermekle birlikte insanların en büyük ilgi odağı haline gelmektedir. İnsanların hızlı yaşam temposuna ayak uydurmakta zorlanmamak adına spor komplekslerine olan ilgileri de artmaktadır (Süllüoğlu, 2018; Şimşek, 2016; Saygın, 2015; Yıldız, 2009).

Son dönemlerde spor ve fiziksel etkinlik hizmetleriyle ilgili sektörlerde geçmişten günümüze büyük değişiklikler yaşandığı göze çarpmaktadır. Artan ekonomi ve rekabet koşullariyla birlikte hızla endüstrileşme sürecine giren spor ve fiziksel etkinlik, bulunduğu sektörün önemli bir merkezi haline gelmiştir (Göksel, 2012; Yıldız, 2008). Bu değişimle birlikte kendisine bağımlı birçok alanı da değişime uğratan (Terekli vd., 2000) spor, belirli kuralları olan, aletli veya aletsiz, ferdi veya takım halinde, yenmek, geçmek ve başarıya ulaşmayı amaçlayan aynı zamanda zevk ve eğlenceli vakit sunan, bedensel ve ruhsal sağlığı koruyan eylemler bütünü olarak tanımlanmaktadır (Yıldız, 2008; Erkan, 1992). Spor tesisleri ise sporcu ve sporseverlerin aktif bir şekilde kullanımına sunulan, bu kullanıcıların ve tesisin ihtiyaç ve beklentilerini karşılayan, her bölgede bulunan, hizmet odaklı mekânlardır (Erkan, 1989).

Spor işletmelerinin giderek artığı düşünülen rekabet koşullarında kendi kurumları adına fark yaratabilmeleri ve kar sağlayabilmeleri için, öncelikli olarak müşteri çıkarını zirvede tutarak müşteri memnuniyeti ve müşteri sadakati oluşturmaları gerektiği şeklinde özetlemek yerinde olacaktır. Müşteri merkezli kurumlar olan spor işletmelerinde müşteri memnuniyetinin öneminin farkında olunmasına rağmen literatürde spor işletmelerinde müşteri memnuniyetine yönelik her ne kadar araştırılmış, üzerinde çalışılmış ve düzenlemeler yapılmış olsa da bu çalışmaların az sayıda olduğu dolayısıyla yeterli olmadığı düşünülmekte olup bu araştırma ile öncelikle müşteri memnuniyetini etkileyen etmenlerin belirlenmesi ve bu etmenlerin müşteri memnuniyeti üzerindeki etkisinin ölçülmesi ile gelecekteki yapılacak çalışmalara ışık tutacağı ve alan yazına katkı sağlayacağı düşünülmektedir. 
$\mathrm{Bu}$ araştırmanın amacı spor işletmelerinde müşteri memnuniyetinin bazı değişkenlere göre incelenmesidir. Bu amaç doğrultusunda aşağıdaki araştırma sorularına yanıt aranmıştır.

Spor işletmelerindeki müşterilerin memnuniyet düzeyleri;

- Cinsiyet,

- Yaş,

- Medeni durum,

- Aylık gelir düzeyi,

- Daha önce bir spor merkezinden yararlanma durumu,

- Şu an yararlanmakta olduğunuz spor merkezi,

- Üyelik süresi,

- Yararlanılan spor tesisinin türü değişkenlerine göre anlamlı farklılık göstermekte midir?

\section{Yöntem}

Bu bölümünde araştırmanın modeli, araştırmanın evren ve örneklemi, verilerin toplanması, veri toplama araçları ve verilerin analiz sürecine ilişkin bilgilere yer verilmiştir.

\section{Araştırma Modeli}

Bu araştırma betimsel ve nedensel karşılaştırma yaklaşım modeliyle yürütülmüştür. Betimsel tarama, geçmişte ya da günümüzde var olan bir durumu olduğu biçimde betimlemeyi amaçlayan bir yaklaşımdır. Araştırmaya konu olan olay, birey ya da nesne, kendi koşulları içinde ve olduğu gibi tanımlanmaya çalışılır (Karasar, 2009). Nedensel karşılaştırma ise, gruplar arasındaki farklılıkların nedenlerini ve sonuçlarını katılımcılar ve koşullar üzerinde bir müdahale olmadan belirlemeyi amaçlayan araştırmalardır. Her iki araştırma modeli de var olan durumları tanımlamaya yönelik araştırmalardır (Büyüköztürk vd., 2014; Fraenkel ve Wallen, 2006; Karasar, 2000).

\section{Araştırma Evren ve Örneklemi}

Araştırmanın evrenini 2019-2020 yılında Yozgat IIl'inde bulunan spor işletmeleri üyeleri oluşturmaktadır. Spor işletmeleri arasından kolayda örnekleme 
tekniği ile seçilen, 2019-2020 kış sezonunda 1 Aralık- 28 Şubat tarihleri arasinda spor işletmelerinde müşteri olan 340 kadın, 260 erkek toplam 600 üye ise çalışmanın örneklemini oluşturmaktadır.

\section{Veri Toplama Araçları}

Ekonomik oluşu, uygulanabilirliği, dağınık ve büyük kitlelerden kısa zamanda bilgi alma imkânı sağlaması nedeniyle araştırmanın yürütülmesinde birincil kaynak araştırmaları arasında yer alan anket veri toplama aracı olarak tercih edilmiştir. Araştırmada kullanılan anket formu iki bölümden oluşmaktadır. İlk bölümde katılımcıların kişisel ve sosyal özelliklerinin belirlenmesine yönelik “Demografik Bilgi Formu (DBF)" (cinsiyet, yaş, medeni durum, eğitim düzeyi, aylık gelir düzeyi, meslek, daha önce bir spor merkezinden yararlanma durumu, şu an yararlanmakta olduğunuz spor merkezi, spor merkezine katılma amacı, üyelik süresi, haftalık kullanım sıklı̆̆ı, spor merkezinde geçirilen süre, spor merkezini kullandığı saatler, bu spor merkezini seçmedeki en önemli sebep ve yararlanılan spor tesisinin türü) kullanılırken, ikinci bölümde ise katılımcıların memnuniyet düzeylerinin belirlenmesine yönelik olan Sevilmiş (2015) tarafından geliştirilen "Spor İşletmelerinde Müşteri Memnuniyeti Ölçeği (SIMMMÖ)" kullanılmıştır.

Spor İşletmelerinde Müşteri Memnuniyeti Ölçeği (SIMMMÖ):Araştırmada hizmet alan katılımciların memnuniyet düzeylerinin belirlenmesi amaciyla Sevilmiş (2015) tarafından geliştirilen yapılan "Spor İşletmelerinde Müşteri Memnuniyeti Ölçeği (SİMMÖ)" kullanılmıştır. Ölçek beş alt boyutlu olup her biri“1 (kesinlikle katılmıyorum) ile 7 (kesinlikle katılıyorum)”arasında derecelendirilen 55 maddelik, 7'li likert tipi bir ölçektir. Ölçeğin alt boyutları sırasiyla;

Gelişim Alt Ölçeği $(1,2$, 3, 4, 5, 6, 7, 8, 9, 10),

Spor Merkezi Kalitesi Alt Ölçeği (İçinde dört alt ölçeğe ayrılmaktadır)

- Program $(20,21,22,23)$,

- Yönetim $(24,25,26,27)$,

- $\quad$ Hizmetler $(28,29,30,31)$,

- $\quad$ Donanim $(32,33,34,35,36,37,38,39)$,

Çalışma Ortamının Niteliği Alt Ölçeği (40, 41, 42, 43, 44),

Spor Eğitmenleri Niteliği Alt Ölçeği (45, 46, 47, 48, 49, 50, 51, 52, 53, 54, 55), 
Memnuniyet Alt Ölçeği (İçinde iki alt ölçeğe ayrılmaktadır)

- Ayrılma İsteği $(11,12,13,14)$,

- Bağlılık $(15,16,17,18,19)$ olarak adlandırılmıştır.

Ölçekte olumlu ve olumsuz ifadeler vardır ve olumsuz ifadeler (Ayrılma isteği; M47, M49, M50) tersine çevrilerek puanlanmaktadır. Tersine çevrilen ifadelerde puanın yüksek olması ayrılma isteğinin olmadığı anlamına gelmektedir. Geliştirilen ölçeğin alt boyutlarının güvenirliği sırasıyla "Gelişim alt ölçeği" 0.87, "Program alt ölçeği" 0.64, "Yönetim alt ölçeği” 0.72, "Hizmetler alt ölçeği" 0.68, “Donanım alt ölçeği” 0.85 , “Çalışma ortamının niteliği alt ölçeği" 0.78, "Spor eğitmenleri niteliği alt ölçeği”" 0.94, "Ayrılma isteği alt ölçeği" 0.92 ve "Bağlllık alt ölçeği" 0.78 olarak hesaplanmıştır.

Gerçekleştirilen bu araştırmada ise ölçeğe ilişkin alt boyutların güvenirliği de sırasıyla "Gelişim alt ölçeği" 0.92, "Program alt ölçeği" 0.70, "Yönetim alt ölçeği" 0.87, "Hizmetler alt ölçeği" 0.73, “Donanım alt ölçeği”" 0.90 , "Çalışma ortamının niteliği alt ölçeği" 0.91, "Spor eğitmenleri niteliği alt ölçeği" 0.94, "Ayrılma isteği alt ölçeği" 0.67 ve "Bağlılık alt ölçeği" 0.67 olarak hesaplanmıştır. Özdamar (1999)'a göre 0.60 ve üzeri Cronbach Alpha değeri ölçeğin güvenilirliği için yeterli olduğu belirtilirken Kalaycı'ya (2010) göre ise 0.80 ve üstü olan değerler için ölçeğin yüksek derecede güvenilir olduğu belirtilmiştir. Dolayısıyla ölçeğe ilişkin tespit edilen iç tutarlılık güvenirlilik katsayılarının kabul düzeyini karşıladığı görülmektedir.

\section{Verilerin Analizi}

Araştırmada elde edilen veriler SPSS 20.0 paket programına aktarılmıştır. Araştırma grubundan elde edilen verilerin istatistiksel analizlerine başlamadan önce verilerin ön hazırlı̆̆ının yapılması ve analizlere uygun hale getirilmesi gerekmektedir. Basıklık ve çarpıklık katsayıları bu süreçte önemli olduğundan dikkat edilmelidir (Şimşek, 2007).Çarpıklık katsayısının 3'ten, basıklık katsayısının ise 10'dan büyük olmaması dağılımın normal olduğunu gösterir (Kline, 2016). Yapılan bu araştırmada ölçeğe ilişkin elde edilen verilerin çarpıklık değerlerinin -0.313 / 2.260 arasında, basıklık değerlerinin -0.099 / 3.410 arasında olduğu tespit edilmiştir. Bu sonuçlara göre verilerin normal dağılım sergilediği belirlenmiş ve istatistiki analizlerde parametrik testler kullanılmıştır. 
Verilerin çözümlenmesinde katılımcların demografik özelliklerini betimlemek amacıyla frekans analizinden ele alınan değişkenlere göre spor tesisleri müşteri memnuniyeti ölçeği alt boyutları arasındaki farklılıkları belirlemek amaciyla t testinden, ANOVA analizinden ve varyansların homojenlik durumuna göre çoklu karşılaştırma testlerinden (Tukey, Tamhane) yararlanılmıştrr. Testlerde istatistiksel anlamlılık düzeyi 0.05 olarak belirlenmiştir.

\section{Bulgular}

Katılımcıların demografik özelliklerine ilişkin bulgular tablo 1'de gösterilmiştir.

Tablo 1. Katılımcilarn demografik özelliklerine ilişkin bulgular

\begin{tabular}{|c|c|c|c|}
\hline & & $\mathbf{N}$ & $\%$ \\
\hline \multirow[t]{2}{*}{ Cinsiyet } & Kadin & 340 & 56.7 \\
\hline & Erkek & 260 & 43.3 \\
\hline \multirow[t]{5}{*}{ Yaş } & 18 ve altı & 242 & 40.3 \\
\hline & $19-29$ & 222 & 37.0 \\
\hline & $30-40$ & 82 & 13.7 \\
\hline & $41-51$ & 38 & 6.3 \\
\hline & 52 ve üzeri & 16 & 2.7 \\
\hline \multirow[t]{2}{*}{ Medeni Durum } & Evli & 125 & 20.8 \\
\hline & Bekar & 475 & 79.2 \\
\hline \multirow[t]{4}{*}{ Aylık Gelir Düzeyi } & 2000 TL ve alt & 287 & 47.8 \\
\hline & 2001 TL-4000 TL & 180 & 30.0 \\
\hline & 4001 TL-6000 TL & 91 & 15.2 \\
\hline & 6001 TLve üzeri & 42 & 7.0 \\
\hline \multirow[t]{2}{*}{ Daha Önce Bir Spor Merkezinden Yararlanma Durumu } & Evet & 400 & 66.7 \\
\hline & Hayır & 200 & 33.3 \\
\hline \multirow[t]{2}{*}{ Yararlanmakta Olduğunuz Spor Merkezi } & Kamu işletmesi & 310 & 51.7 \\
\hline & Özel işletme & 290 & 48.3 \\
\hline \multirow[t]{4}{*}{ Üyelik Süresi } & 1 aydan az & 91 & 15.2 \\
\hline & $1-6$ ay & 250 & 41.7 \\
\hline & 6 ay-1 yıl arası & 109 & 18.2 \\
\hline & 1 yıldan fazla & 150 & 25.0 \\
\hline \multirow[t]{8}{*}{ Yararlanılan Spor Tesisinin Türü } & Yüzme havuzu & 78 & 13.0 \\
\hline & Fitness & 162 & 27.0 \\
\hline & $\begin{array}{l}\text { Plates/Step-Aero- } \\
\text { bik/Zumba }\end{array}$ & 75 & 12.5 \\
\hline & Halı saha & 45 & 7.5 \\
\hline & Tenis kortu & 4 & .7 \\
\hline & Stadyum & 108 & 18.0 \\
\hline & Spor salonu & 111 & 18.5 \\
\hline & Diğger & 17 & 2.8 \\
\hline
\end{tabular}

Tablo 1 incelendiğinde katılımcıların 340'1 (\%56.7) kadın, 260'1 (\%43.3) erkektir. Yaş aralıklarına bakıldığında 242'si (\%40.3) 18 ve altı, 222'si (\%37.0) 19- 
29, 82' si (\% 13.7) 30-40, 38'i (\%6.3) 41-51 ve 16 's1 (\%2.7) 51 ve üzeri yaşındadır. 125 'i (\%20.8) evli iken 475'i (\%79.2) de bekardır. Aylık gelir düzeylerine bakıldığında 287'si (\%47.8) 2000 TL ve altında, 180'i (\%30.0) 2001 TL-4000 TL arasında, 91'i (\%15.2) 4001 TL-6000 TL arasında ve 42'si (\%7.0) 6001 TL üzeri bir gelire sahiptir. Daha önce bir spor merkezinden yararlanma durumu incelendiğinde 400'ü (\%66.7) evet, 200'ü (\%33.3) hayır yanıtını vermiştir. Katılımcıların 310'u (\%51.7) yararlanmakta oldukları spor merkezinin kamu işletmesi, 290'1 (\%48.3) ise özel işletme olduğunu belirtmiştir. Katılımcıların 91'i (\%15.2) 1 aydan az, 250'si (\%41.7) 1-6 ay, 109'u (\%18.2) 6 ay-1 yıl arası ve 150'si (\%25.0) 1 yıldan fazla üyelik süresine sahiptir. Katılımcıların 78'nin (\%13.0) yararlandığı spor tesisinin türü yüzme havuzu, 162'sinin (\%27.0) fitness, 75'inin (\%12.5) plates/step-aerobik/zumba, 45'inin (\%7.5) halı saha, $4^{\prime}$ ünün (\%.7) tenis kortu, 108'inin (\%18.0) stadyum (futbol, atletizm vs.), 111'inin (\%18.5) spor salonu (voleybol, hentbol, futsal, badminton, boks, taekwondo vs.), 17 'sinin (\%2.8) diğer seçeneğidir.

Tablo 2'de Spor İşletmeleri Müşteri Memnuniyeti Ölçeği alt boyutları puan ortalamasına ilişkin bulgulara yer verilmiştir.

Tablo 2. Spor işletmeleri müşteri memnuniyeti ölçeği alt boyutlan puan ortalamasına ilişkin bulgular

\begin{tabular}{llll}
\hline & $\mathbf{N}$ & $\overline{\mathbf{x}}$ & $\mathbf{s s}$ \\
\hline Gelişim & 600 & 5.52 & 1.23 \\
Program & 600 & 5.60 & 1.22 \\
Yönetim & 600 & 5.84 & 1.35 \\
Hizmetler & 600 & 4.69 & 1.51 \\
Donanmm & 600 & 5.30 & 1.33 \\
Çalışsma Ortamını Niteliği & 600 & 5.72 & 1.30 \\
Spor Eğitmenleri Niteliği & 600 & 5.96 & 1.20 \\
Ayrllma İsteği & 600 & 4.96 & 1.53 \\
Bağllılk & 600 & 5.42 & 1.29 \\
\hline
\end{tabular}

Tablo 2 incelendiğinde; Spor İşletmeleri Müşteri Memnuniyeti Ölçeği alt boyutlarının en önemlisinin spor eğitmenleri niteliği boyutu olduğu belirlenmiştir. Katılımcların spor işletmeleri memnuniyet düzeylerinin yüksek seviyede olduğu bulunmuştur.

Tablo 3'de cinsiyet değişkenine göre Spor İşletmeleri Müşteri Memnuniyeti Ölçeği alt boyutları puan ortalaması $\mathrm{t}$ testi bulgularına yer verilmiştir. 
Tablo 3. Cinsiyet değişkenine göre spor işletmeleri müşteri memnuniyeti ölçeği alt boyutları puan ortalamasi $t$ testi bulgularn

\begin{tabular}{lllllcc}
\hline & Cinsiyet & $\mathbf{N}$ & $\overline{\mathbf{x}}$ & $\mathbf{s s}$ & $\mathbf{t}$ & $\mathbf{p}$ \\
\hline Gelişim Boyutu & Kadın & 340 & 5.53 & 1.12 & .294 & .769 \\
& Erkek & 260 & 5.50 & 1.37 & & \\
\hline Program Boyutu & Kadın & 340 & 5.64 & 1.23 & .887 & .376 \\
& Erkek & 260 & 5.55 & 1.20 & & \\
\hline Yönetim Boyutu & Kadın & 340 & 5.97 & 1.27 & 2.540 & $.011^{*}$ \\
& Erkek & 260 & 5.68 & 1.44 & & \\
\hline Hizmetler Boyutu & Kadın & 340 & 4.56 & 1.52 & -2.450 & $.015^{*}$ \\
& Erkek & 260 & 4.87 & 1.48 & & \\
\hline Donanım Boyutu & Kadın & 340 & 5.25 & 1.28 & -956 & .339 \\
& Erkek & 260 & 5.36 & 1.40 & & \\
\hline Çalışma Ortamının Niteliği Bo- & Kadın & 340 & 5.79 & 1.24 & 1.603 & .110 \\
yutu & Erkek & 260 & 5.62 & 1.38 & & \\
\hline Spor Eğitmenleri Niteliği Bo- & Kadın & 340 & 6.11 & 1.07 & 3.252 & $.001^{*}$ \\
yutu & Erkek & 260 & 5.78 & 1.32 & & \\
\hline Ayrılma İsteği Boyutu & Kadın & 340 & 5.03 & 1.54 & 1.266 & .206 \\
& Erkek & 260 & 4.87 & 1.52 & & \\
\hline Bağlllık Boyutu & Kadın & 340 & 5.34 & 1.24 & -1.693 & .091 \\
& Erkek & 260 & 5.52 & 1.35 & & \\
\hline
\end{tabular}

${ }^{*} p<.05$

Tablo 3 incelendiğinde; cinsiyet değişkenine göre Spor İşletmeleri Müşteri Memnuniyeti Ölçeği yönetim, hizmetler ve spor eğitmenleri niteliği alt boyutları puan ortalaması arasında istatistiksel olarak anlamlı farklar tespit edilmiştir ( $\mathrm{p}<.05)$. Kadınların yönetimden ve spor eğitmenleri niteliğinden memnun kalma düzeylerinin erkeklere göre daha yüksek seviyede olduğu belirlenirken, hizmet boyutunda memnun kalma düzeylerinin ise erkeklere göre daha düşük seviyede olduğu belirlenmiştir. Ölçeğe ilişkin diğer alt boyut puan ortalamaları arasında ise istatistiksel olarak herhangi bir anlamlı fark tespit edilmemiştir ( $\mathrm{p}>.05)$

Tablo 4'de yaş değişkenine göre Spor İşletmeleri Müşteri Memnuniyeti Ölçeği alt boyutları puan ortalaması Anova Analizi bulgularına yer verilmiştir. 
Tablo 4. Yaş değişkenine göre Spor Iş̧letmeleri Müş̧teri Memnuniyeti Ölçeği alt boyutlan puan ortalamast Anova Analizi bulgular

\begin{tabular}{|c|c|c|c|c|c|c|c|c|c|}
\hline & Grup & $\mathbf{N}$ & $\bar{x}$ & Ss & Var. K. & sd & $\mathbf{F}$ & $\mathrm{p}$ & $\begin{array}{l}\text { Anlamlı } \\
\text { Fark }\end{array}$ \\
\hline \multirow{5}{*}{ Gelişim } & 18 ve altı(1) & 242 & 5.53 & 1.28 & G.A & 4 & 1.873 & .114 & \multirow{5}{*}{ - } \\
\hline & $19-29(2)$ & 222 & 5.39 & 1.22 & G.İ & 595 & & & \\
\hline & $30-40(3)$ & 82 & 5.79 & 1.21 & Toplam & 599 & & & \\
\hline & $41-51(4)$ & 38 & 5.48 & 1.08 & & & & & \\
\hline & 52 ve üzeri(5) & 16 & 5.85 & .92 & & & & & \\
\hline \multirow{5}{*}{ Program } & 18 ve altı(1) & 242 & 5.64 & 1.10 & G.A & 4 & 2.389 & $.050^{*}$ & \multirow{5}{*}{$3>4$} \\
\hline & $19-29(2)$ & 222 & 5.53 & 1.38 & G.İ & 595 & & & \\
\hline & $30-40(3)$ & 82 & 5.88 & 1.09 & Toplam & 599 & & & \\
\hline & $41-51(4)$ & 38 & 5.20 & 1.25 & & & & & \\
\hline & 52 ve üzeri(5) & 16 & 5.46 & .85 & & & & & \\
\hline \multirow{5}{*}{ Yönetim } & 18 ve altı(1) & 242 & 5.86 & 1.34 & G.A & 4 & 1.663 & .157 & \multirow{5}{*}{-} \\
\hline & $19-29(2)$ & 222 & 5.74 & 1.45 & G.İ & 595 & & & \\
\hline & $30-40(3)$ & 82 & 6.12 & 1.24 & Toplam & 599 & & & \\
\hline & $41-51(4)$ & 38 & 5.61 & 1.23 & & & & & \\
\hline & 52 ve üzeri(5) & 16 & 6.17 & .89 & & & & & \\
\hline \multirow{5}{*}{ Hizmetler } & 18 ve altı(1) & 242 & 4.59 & 1.52 & G.A & 4 & 2.909 & $.021^{*}$ & \multirow{5}{*}{$3>1,2$} \\
\hline & $19-29(2)$ & 222 & 4.61 & 1.48 & G.İ & 595 & & & \\
\hline & $30-40(3)$ & 82 & 5.21 & 1.54 & Toplam & 599 & & & \\
\hline & $41-51(4)$ & 38 & 4.70 & 1.51 & & & & & \\
\hline & 52 ve üzeri(5) & 16 & 4.75 & 1.19 & & & & & \\
\hline \multirow{5}{*}{ Donanim } & 18 ve alt $(1)$ & 242 & 5.29 & 1.33 & G.A & 4 & 1.956 & .100 & \multirow[b]{5}{*}{ - } \\
\hline & $19-29(2)$ & 222 & 5.25 & 1.34 & G.İ & 595 & & & \\
\hline & $30-40(3)$ & 82 & 5.63 & 1.23 & Toplam & 599 & & & \\
\hline & $41-51(4)$ & 38 & 5.03 & 1.35 & & & & & \\
\hline & 52 ve üzeri(5) & 16 & 4.97 & 1.41 & & & & & \\
\hline \multirow{5}{*}{$\begin{array}{l}\text { Çalışma } \\
\text { Ortamının } \\
\text { Niteliği }\end{array}$} & 18 ve altı(1) & 242 & 5.65 & 1.43 & G.A & 4 & 1.944 & .102 & \\
\hline & $19-29(2)$ & 222 & 5.66 & 1.29 & G.I & 595 & & & \multirow{4}{*}{ - } \\
\hline & $30-40(3)$ & 82 & 6.05 & 1.14 & Toplam & 599 & & & \\
\hline & $41-51(4)$ & 38 & 5.88 & .97 & & & & & \\
\hline & 52 ve üzeri(5) & 16 & 5.40 & .77 & & & & & \\
\hline \multirow{5}{*}{$\begin{array}{l}\text { Spor Eğit- } \\
\text { menlr } \\
\text { Niteliği }\end{array}$} & 18 ve altı(1) & 242 & 5.98 & 1.29 & G.A & 4 & 2.336 & .054 & \\
\hline & $19-29(2)$ & 222 & 5.80 & 1.25 & G.I & 595 & & & \multirow{4}{*}{ - } \\
\hline & $30-40(3)$ & 82 & 6.20 & .93 & Toplam & 599 & & & \\
\hline & $41-51(4)$ & 38 & 6.16 & .77 & & & & & \\
\hline & 52 ve üzeri(5) & 16 & 6.27 & .63 & & & & & \\
\hline \multirow{5}{*}{$\begin{array}{l}\text { Ayrulma İs- } \\
\text { teği }\end{array}$} & 18 ve altı(1) & 242 & 5.27 & 1.39 & G.A & 4 & 4.551 & $.001^{*}$ & \multirow{5}{*}{$1>2$} \\
\hline & $19-29(2)$ & 222 & 4.78 & 1.58 & G.İ & 595 & & & \\
\hline & $30-40(3)$ & 82 & 4.80 & 1.67 & Toplam & 599 & & & \\
\hline & $41-51(4)$ & 38 & 4.51 & 1.58 & & & & & \\
\hline & 52 ve üzeri(5) & 16 & 4.65 & 1.45 & & & & & \\
\hline \multirow{5}{*}{ Bağlılık } & 18 ve altı(1) & 242 & 5.58 & 1.2 & G.A & 4 & 2.099 & .080 & \multirow{5}{*}{ 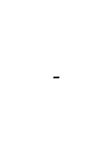 } \\
\hline & $19-29(2)$ & 222 & 5.26 & 1.34 & G.İ & 595 & & & \\
\hline & $30-40(3)$ & 82 & 5.37 & 1.36 & Toplam & 599 & & & \\
\hline & $41-51(4)$ & 38 & 5.51 & 1.01 & & & & & \\
\hline & 52 ve üzeri(5) & 16 & 5.08 & .84 & & & & & \\
\hline
\end{tabular}


Tablo 4 incelendiğinde; yaş değişkenine göre Spor İşletmeleri Müşteri Memnuniyeti Ölçeği program, hizmetler ve ayrılma isteği alt boyutları puan ortalamaları arasında istatistiksel olarak anlamlı farklar tespit edilmiştir ( $\mathrm{p}<.05)$. Program boyutunda 30-40 yaş aralığındaki katılımcıların 41-51 yaş aralığındaki katılımcılara göre yararlandıkları spor işletmelerinden memnuniyet düzeyleri daha yüksek seviyededir. Hizmetler boyutunda 30-40 yaş aralığındaki katılımcıların 18 yaş ve altı ile 19-29 yaş aralığındaki katılımclara göre yararlandıkları spor işletmelerinden memnuniyet düzeyleri daha yüksek seviyededir. Ayrılma isteği boyutunda ise 18 yaş ve altındaki katılımcıların 19-29 yaş aralığındaki katılımcılara göre yararlandıkları spor işletmelerinden memnuniyet düzeyleri daha yüksek seviyededir. Ölçeğe ilişkin diğer alt boyut puan ortalamaları arasında ise istatistiksel olarak herhangi bir anlamlı fark tespit edilmemiştir ( $>$ >05). Tablo 5 'de medeni durum değişkenine göre Spor İşletmeleri Müşteri Memnuniyeti Ölçeği alt boyutları puan ortalaması t Testi bulgularına yer verilmiştir.

Tablo 5. Medeni durum değişkenine göre spor işletmeleri müşteri memnuniyeti ölçeği alt boyutlar puan ortalaması t testi bulgularn

\begin{tabular}{|c|c|c|c|c|c|c|}
\hline & $\begin{array}{l}\text { Medeni } \\
\text { Durum }\end{array}$ & $\mathbf{N}$ & $\bar{x}$ & ss & $t$ & $\mathbf{P}$ \\
\hline \multirow[t]{2}{*}{ Gelişim Boyutu } & Evli & 125 & 5.66 & 1.18 & 1.473 & .141 \\
\hline & Bekar & 475 & 5.48 & 1.25 & & \\
\hline \multirow[t]{2}{*}{ Program Boyutu } & Evli & 125 & 5.68 & 1.32 & .859 & .391 \\
\hline & Bekar & 475 & 5.58 & 1.19 & & \\
\hline \multirow[t]{2}{*}{ Yönetim Boyutu } & Evli & 125 & 5.81 & 1.43 & -.302 & .762 \\
\hline & Bekar & 475 & 5.85 & 1.34 & & \\
\hline \multirow[t]{2}{*}{ Hizmetler Boyutu } & Evli & 125 & 4.62 & 1.58 & -.660 & .510 \\
\hline & Bekar & 475 & 4.72 & 1.49 & & \\
\hline \multirow[t]{2}{*}{ Donanım Boyutu } & Evli & 125 & 5.34 & 1.31 & .440 & .660 \\
\hline & Bekar & 475 & 5.28 & 1.34 & & \\
\hline \multirow[t]{2}{*}{ Çalışma Ortamının Niteliği Boyutu } & Evli & 125 & 5.86 & 1.11 & 1.514 & .131 \\
\hline & Bekar & 475 & 5.68 & 1.35 & & \\
\hline \multirow[t]{2}{*}{ Spor Eğitmenleri Niteliği Boyutu } & Evli & 125 & 6.15 & 1.04 & 1.923 & .055 \\
\hline & Bekar & 475 & 5.92 & 1.23 & & \\
\hline \multirow[t]{2}{*}{ Ayrilma İsteği Boyutu } & Evli & 125 & 4.81 & 1.56 & -1.266 & .206 \\
\hline & Bekar & 475 & 5.00 & 1.52 & & \\
\hline \multirow[t]{2}{*}{ Bağlılık Boyutu } & Evli & 125 & 5.40 & 1.14 & -.182 & .856 \\
\hline & Bekar & 475 & 5.42 & 1.33 & & \\
\hline
\end{tabular}

${ }^{*} p<.05$

Tablo 5 incelendiğinde; medeni durum değişkenine göre Spor İşletmeleri 
Müşteri Memnuniyeti Ölçeği alt boyutları puan ortalaması arasında istatistiksel olarak anlamlı bir fark tespit edilmemiştir ( $p>.05)$.

Tablo 6'da aylık gelir düzeyi değişkenine göre Spor İşletmeleri Müşteri Memnuniyeti Ölçeği alt boyutları puan ortalaması Anova Analizi bulgularına yer verilmiştir.

Tablo 6. Aylık gelir düzeyi değişkenine göre spor işletmeleri müşteri memnuniyeti ölçeği alt boyutlarn puan ortalaması Anova analizi bulgular

\begin{tabular}{|c|c|c|c|c|c|c|c|c|c|}
\hline & Grup & $\mathbf{N}$ & $\bar{x}$ & ss & Var. K. & sd & $\mathbf{F}$ & $\mathrm{p}$ & $\begin{array}{l}\text { Anlamlı } \\
\text { Fark }\end{array}$ \\
\hline \multirow{4}{*}{ Gelişim } & 2000 TL ve altı(1) & 287 & 5.69 & 1.08 & G.A & 3 & 8.054 & $.000^{*}$ & \multirow{4}{*}{$1,4>2$} \\
\hline & 2001 TL-4000 TL(2) & 180 & 5.17 & 1.40 & G.İ & 596 & & & \\
\hline & 4001 TL-6000 TL(3) & 91 & 5.51 & 1.07 & Toplam & 599 & & & \\
\hline & 6001 TL ve üzeri(4) & 42 & 5.87 & 1.49 & & & & & \\
\hline \multirow{4}{*}{ Program } & 2000 TL ve altı(1) & 287 & 5.66 & 1.07 & G.A & 3 & 2.668 & $.047^{*}$ & \multirow{4}{*}{$4>2$} \\
\hline & 2001 TL-4000 TL(2) & 180 & 5.40 & 1.31 & G.İ & 596 & & & \\
\hline & 4001 TL-6000 TL(3) & 91 & 5.66 & 1.31 & Toplam & 599 & & & \\
\hline & 6001 TL ve üzeri(4) & 42 & 5.88 & 1.42 & & & & & \\
\hline \multirow{4}{*}{ Yönetim } & 2000 TL ve altı(1) & 287 & 6.00 & 1.18 & G.A & 3 & 9.253 & $.000^{*}$ & \multirow{4}{*}{$1,3>2$} \\
\hline & 2001 TL-4000 TL(2) & 180 & 5.41 & 1.57 & G.İ & 596 & & & \\
\hline & 4001 TL-6000 TL(3) & 91 & 6.13 & 1.20 & Toplam & 599 & & & \\
\hline & 6001 TL ve üzeri(4) & 42 & 5.97 & 1.45 & & & & & \\
\hline \multirow{4}{*}{$\begin{array}{l}\text { Hizmet- } \\
\text { ler }\end{array}$} & 2000 TL ve altı(1) & 287 & 4.70 & 1.54 & G.A & 3 & 1.469 & .222 & \multirow[b]{4}{*}{-} \\
\hline & 2001 TL-4000 TL(2) & 180 & 4.55 & 1.49 & G.I & 596 & & & \\
\hline & 4001 TL-6000 TL(3) & 91 & 4.78 & 1.46 & Toplam & 599 & & & \\
\hline & 6001 TL ve üzeri(4) & 42 & 5.07 & 1.46 & & & & & \\
\hline \multirow{4}{*}{$\begin{array}{l}\text { Dona- } \\
\text { nim }\end{array}$} & 2000 TL ve altı(1) & 287 & 5.33 & 1.37 & G.A & 3 & 1.705 & .165 & \\
\hline & 2001 TL-4000 TL(2) & 180 & 5.17 & 1.20 & G.I & 596 & & & \\
\hline & 4001 TL-6000 TL(3) & 91 & 5.28 & 1.37 & Toplam & 599 & & & \\
\hline & 6001 TL ve üzeri(4) & 42 & 5.66 & 1.48 & & & & & \\
\hline \multirow{4}{*}{$\begin{array}{l}\text { Çalışma } \\
\text { Ortamı- } \\
\text { nun } \\
\text { Niteliği }\end{array}$} & 2000 TL ve altı(1) & 287 & 5.75 & 1.33 & G.A & 3 & 2.113 & .097 & \multirow[b]{4}{*}{-} \\
\hline & 2001 TL-4000 TL(2) & 180 & 5.57 & 1.23 & G.İ & 596 & & & \\
\hline & 4001 TL-6000 TL(3) & 91 & 5.97 & 1.16 & Toplam & 599 & & & \\
\hline & 6001 TL ve üzeri(4) & 42 & 5.59 & 1.66 & & & & & \\
\hline \multirow{4}{*}{$\begin{array}{l}\text { Spor } \\
\text { Eğit- } \\
\text { menleri } \\
\text { Niteliği } \\
\end{array}$} & 2000 TL ve altı(1) & 287 & 6.10 & 1.11 & G.A & 3 & 5.809 & $.001^{*}$ & \multirow{4}{*}{$1,3>2$} \\
\hline & 2001 TL-4000 TL(2) & 180 & 5.68 & 1.23 & G.I & 596 & & & \\
\hline & 4001 TL-6000 TL(3) & 91 & 6.16 & .96 & Toplam & 599 & & & \\
\hline & 6001 TL ve üzeri(4) & 42 & 5.79 & 1.73 & & & & & \\
\hline \multirow{4}{*}{$\begin{array}{l}\text { Ayrulma } \\
\text { İsteği }\end{array}$} & 2000 TL ve altı(1) & 287 & 5.09 & 1.51 & G.A & 3 & 5.081 & $.002^{*}$ & \multirow{4}{*}{$1,3>4$} \\
\hline & 2001 TL-4000 TL(2) & 180 & 4.79 & 1.46 & G.İ & 596 & & & \\
\hline & 4001 TL-6000 TL(3) & 91 & 5.21 & 1.60 & Toplam & 599 & & & \\
\hline & 6001 TL ve üzeri(4) & 42 & 4.28 & 1.57 & & & & & \\
\hline \multirow{4}{*}{ Bağlilık } & 2000 TL ve altı(1) & 287 & 5.58 & 1.23 & G.A & 3 & 4.547 & $.004^{*}$ & \multirow{4}{*}{$1>2$} \\
\hline & 2001 TL-4000 TL(2) & 180 & 5.28 & 1.10 & G.I & 596 & & & \\
\hline & 4001 TL-6000 TL(3) & 91 & 5.38 & 1.37 & Toplam & 599 & & & \\
\hline & 6001 TL ve üzeri(4) & 42 & 4.91 & 1.90 & & & & & \\
\hline
\end{tabular}


Tablo 6 incelendiğinde; aylık gelir düzeyi değişkenine göre Spor İşletmeleri Müşteri Memnuniyeti Ölçeği gelişim, program, yönetim, spor eğitmenleri niteliği, ayrılma isteği ve bağlılık alt boyutları puan ortalaması arasında istatistiksel olarak anlamlı farklar tespit edilmiştir $(\mathrm{p}<.05)$.

Gelişim boyutunda aylık gelir düzeyi 2000 TL ve altı ile 6000 TL ve üzeri olan katılımcıların aylık gelir düzeyi 2001 TL - 4000 TL olan katılımclara göre yararlandıkları spor işletmelerinden memnuniyet düzeyleri daha yüksek seviyededir. Program boyutunda aylık gelir düzeyi 6000 TL ve üzeri olan katılımcıların aylık gelir düzeyi 2001 TL - 4000 TL olan katılımcılara göre yararlandıkları spor işletmelerinden memnuniyet düzeyleri daha yüksek seviyededir. Yönetim ve spor eğitmenleri niteliği boyutlarında aylık gelir düzeyi 2000 TL ve altı ile 4001 TL - 6000 TL olan katılımciların aylık gelir düzeyi 2001 TL - 4000 TL olan katılımclara göre yararlandıkları spor işletmelerinden memnuniyet düzeyleri daha yüksek seviyededir. Ayrılma isteği boyutunda aylık gelir düzeyi 2000 TL ve altı ile 4001 TL - 6000 TL olan katılımciların aylık gelir düzeyi 6001 TL ve üzeri olan katılımcılara göre yararlandıkları spor işletmelerinden memnuniyet düzeyleri daha yüksek seviyededir.

Bağlılık boyutunda aylık gelir düzeyi 2000 TL ve altı olan katılımcıların aylık gelir düzeyi 2001 TL - 4000 TL olan katılımclara göre yararlandıkları spor işletmelerinden memnuniyet düzeyleri daha yüksek seviyededir. Ölçeğe ilişkin diğer alt boyut puan ortalamaları arasında ise istatistiksel olarak herhangi bir anlamlı fark tespit edilmemiştir ( $\mathrm{p}>.05)$

Tablo 7'de daha önce bir spor merkezinden yararlanma durumu değişkenine göre Spor İşletmeleri Müşteri Memnuniyeti Ölçeği alt boyutları puan ortalaması $\mathrm{t}$ testi bulgularına yer verilmiştir.

Tablo 7 incelendiğinde; daha önce bir spor merkezinden yararlanma durumu değişkenine göre Spor İşletmeleri Müşteri Memnuniyeti Ölçeği donanım ve bağlılık alt boyutları puan ortalaması arasında istatistiksel olarak anlamlı farklar tespit edilmiştir ( $\mathrm{p}<.05)$.

Donanım ve bağlllık boyutlarında daha önce bir spor merkezinden yararlanma durumu değişkenine 'hayır' yanıtı veren katılımcıların 'evet' yanıtı veren katılımclara göre yararlandıkları spor işletmelerinden memnuniyet düzeyleri daha yüksek seviyededir. Ölçeğe ilişkin diğer alt boyut puan ortalamaları arasında ise istatistiksel olarak herhangi bir anlamlı fark tespit edilmemiştir ( $>$ >.05) 
Tablo 7. Daha önce bir spor merkezinden yararlanma durumu değişkenine göre spor işletmeleri müşteri memnuniyeti ölçeği alt boyutları puan ortalaması t testi bulguları

\begin{tabular}{|c|c|c|c|c|c|c|}
\hline & $\begin{array}{l}\text { Spor Mer. } \\
\text { Yar. Dur. }\end{array}$ & $\mathbf{N}$ & $\overline{\bar{x}}$ & ss & $t$ & $\mathbf{P}$ \\
\hline \multirow[t]{2}{*}{ Gelişim Boyutu } & Evet & 400 & 5.52 & 1.21 & .067 & .946 \\
\hline & Hayır & 200 & 5.51 & 1.29 & & \\
\hline \multirow[t]{2}{*}{ Program Boyutu } & Evet & 400 & 5.59 & 1.27 & -.337 & .737 \\
\hline & Hayır & 200 & 5.62 & 1.12 & & \\
\hline \multirow[t]{2}{*}{ Yönetim Boyutu } & Evet & 400 & 5.88 & 1.31 & .944 & .346 \\
\hline & Hayır & 200 & 5.77 & 1.43 & & \\
\hline \multirow[t]{2}{*}{ Hizmetler Boyutu } & Evet & 400 & 4.64 & 1.54 & -1.349 & .178 \\
\hline & Hayır & 200 & 4.81 & 1.45 & & \\
\hline \multirow[t]{2}{*}{ Donanim Boyutu } & Evet & 400 & 5.21 & 1.32 & -2.175 & $.030^{*}$ \\
\hline & Hayır & 200 & 5.46 & 1.35 & & \\
\hline \multirow[t]{2}{*}{ Çalışma Ortamının Niteliği Boyutu } & Evet & 400 & 5.69 & 1.27 & -.819 & .413 \\
\hline & Hayır & 200 & 5.78 & 1.38 & & \\
\hline \multirow[t]{2}{*}{ Spor Eğitmenleri Niteliği Boyutu } & Evet & 400 & 5.94 & 1.21 & -.684 & .494 \\
\hline & Hayır & 200 & 6.01 & 1.17 & & \\
\hline \multirow[t]{2}{*}{ Ayrilma İsteği Boyutu } & Evet & 400 & 4.95 & 1.50 & -.263 & .793 \\
\hline & Hayır & 200 & 4.99 & 1.59 & & \\
\hline \multirow[t]{2}{*}{ Bağlılık Boyutu } & Evet & 400 & 5.29 & 1.30 & -3.513 & $.000^{*}$ \\
\hline & Hayır & 200 & 5.68 & 1.21 & & \\
\hline
\end{tabular}

Tablo 8'de yararlanmakta olduğunuz spor merkezi değişkenine göre Spor İşletmeleri Müşteri Memnuniyeti Ölçeği alt boyutları puan ortalaması $\mathrm{t}$ testi bulgularına yer verilmiştir.

Tablo 8. Yararlanmakta olduğunuz spor merkezi değişkenine göre spor işletmeleri müşteri memnuniyeti ölçeği alt boyutları puan ortalaması t testi bulguları

\begin{tabular}{lllllll} 
& Yararlanmakta Olduğu- & $\mathbf{N}$ & $\mathbf{x}$ & ss & $\mathbf{t}$ & $\mathbf{P}$ \\
& nuz & & & & & \\
& Spor Merkezi & & & & & \\
\hline Gelişim Boyutu & Kamu & 310 & 5.39 & 1.30 & -2.558 & $.011^{*}$ \\
& Özel & 290 & 5.65 & 1.15 & & \\
\hline Program Boyutu & Kamu & 310 & 5.48 & 1.21 & -2.419 & $.016^{*}$ \\
& Özel & 290 & 5.72 & 1.21 & & \\
\hline Yönetim Boyutu & Kamu & 310 & 5.74 & 1.45 & -1.868 & .062 \\
& Özel & 290 & 5.95 & 1.24 & & \\
\hline Hizmetler Boyutu & Kamu & 310 & 4.56 & 1.52 & -2.211 & $.027^{*}$ \\
& Özel & 290 & 4.84 & 1.49 & & \\
\hline Donanim Boyutu & Kamu & 310 & 5.21 & 1.37 & -1.688 & .092 \\
& Özel & 290 & 5.39 & 1.29 & & \\
\hline Çalışma Ortamının Niteliği Boyutu & Kamu & 310 & 5.61 & 1.34 & -2.083 & $.038^{*}$ \\
& Özel & 290 & 5.83 & 1.26 & & \\
\hline Spor Eğitmenleri Niteliği Boyutu & Kamu & 310 & 5.92 & 1.20 & -.981 & .327 \\
& Özel & 290 & 6.01 & 1.19 & & \\
\hline Ayrilma İsteği Boyutu & Kamu & 310 & 5.03 & 1.49 & 1.135 & .257 \\
& Özel & 290 & 4.89 & 1.57 & & \\
\hline
\end{tabular}




\begin{tabular}{lllllll}
\hline Bağlllık Boyutu & Kamu & 310 & 5.49 & 1.27 & 1.449 & .148 \\
& Özel & 290 & 5.34 & 1.30 & & \\
\hline
\end{tabular}

$" p<.05, " * p<.01$

Tablo 8 incelendiğinde; yararlanmakta olduğunuz spor merkezi değişkenine göre Spor İşletmeleri Müşteri Memnuniyeti Ölçeği gelişim, program ve çalışma ortamının niteliği alt boyutları puan ortalaması arasında istatistiksel olarak anlamlı farklar tespit edilmiştir $(\mathrm{p}<.05)$.

Gelişim, program, hizmetler ve çalışma ortamının niteliği boyutlarında yararlanmakta olduğunuz spor merkezi değişkenine 'özel işletme' yanıtı veren katılımcıların 'kamu işletmesi' yanıtı veren katılımcılara göre yararlandıkları spor işletmelerinden memnuniyet düzeyleri daha yüksek seviyededir. Ölçeğe ilişkin diğer alt boyut puan ortalamaları arasında ise istatistiksel olarak herhangi bir anlamlı fark tespit edilmemiştir $(\mathrm{p}>.05)$

Tablo 9' da üyelik süresi değişkenine göre Spor İşletmeleri Müşteri Memnuniyeti Ölçeği alt boyutları puan ortalaması Anova Analizi bulgularına yer verilmiştir.

Tablo 9. Üyelik süresi değişkenine göre spor işletmeleri müşteri memnuniyeti ölçeği alt boyutlar puan ortalamasi Anova analizi bulgularn

\begin{tabular}{|c|c|c|c|c|c|c|c|c|c|}
\hline & Grup & $\mathbf{N}$ & $\bar{x}$ & ss & Var. K. & sd & $\mathbf{F}$ & $\mathrm{p}$ & $\begin{array}{l}\text { An- } \\
\text { lamlı } \\
\text { Fark }\end{array}$ \\
\hline \multirow{4}{*}{ Gelişim } & 1 aydan az(1) & 91 & 5.21 & 1.54 & G.A & 3 & 11.509 & $.000^{*}$ & \multirow{4}{*}{$3,4>1,2$} \\
\hline & $1-6$ ay $(2)$ & 250 & 5.29 & 1.20 & G.İ & 596 & & & \\
\hline & 6 ay-1 y1l(3) & 109 & 5.81 & 1.06 & Toplam & 599 & & & \\
\hline & 1 yıldan fazla(4) & 150 & 5.88 & 1.07 & & & & & \\
\hline \multirow{4}{*}{ Program } & 1 aydan az(1) & 91 & 5.40 & 1.51 & G.A & 3 & 2.552 & .055 & \multirow{4}{*}{ - } \\
\hline & $1-6$ ay(2) & 250 & 5.52 & 1.30 & G.I & 596 & & & \\
\hline & 6 ay-1 yıl(3) & 109 & 5.68 & .98 & Toplam & 599 & & & \\
\hline & 1 yıldan fazla(4) & 150 & 5.79 & .98 & & & & & \\
\hline \multirow{4}{*}{ Yönetim } & 1 aydan az(1) & 91 & 5.40 & 1.55 & G.A & 3 & 8.692 & $.000^{*}$ & \multirow{4}{*}{$\begin{array}{l}3>1 \\
4>1,2\end{array}$} \\
\hline & $1-6$ ay $(2)$ & 250 & 5.72 & 1.42 & G.İ & 596 & & & \\
\hline & 6 ay-1 yıl(3) & 109 & 5.96 & 1.27 & Toplam & 599 & & & \\
\hline & 1 yıldan fazla(4) & 150 & 6.24 & 1.03 & & & & & \\
\hline \multirow{4}{*}{ Hizmetler } & 1 aydan az(1) & 91 & 4.93 & 1.56 & G.A & 3 & 2.785 & $.040^{*}$ & \multirow{4}{*}{$1>3$} \\
\hline & $1-6$ ay $(2)$ & 250 & 4.61 & 1.49 & G.I & 596 & & & \\
\hline & 6 ay-1 yıl(3) & 109 & 4.45 & 1.51 & Toplam & 599 & & & \\
\hline & 1 yıldan fazla(4) & 150 & 4.88 & 1.49 & & & & & \\
\hline \multirow{4}{*}{ Donanim } & 1 aydan az(1) & 91 & 5.29 & 1.43 & G.A & 3 & 1.395 & .243 & \multirow{4}{*}{-} \\
\hline & $1-6$ ay $(2)$ & 250 & 5.28 & 1.22 & G.I & 596 & & & \\
\hline & 6 ay-1 yıl(3) & 109 & 5.11 & 1.48 & Toplam & 599 & & & \\
\hline & 1 yıldan fazla(4) & 150 & 5.46 & 1.33 & & & & & \\
\hline
\end{tabular}




\begin{tabular}{|c|c|c|c|c|c|c|c|c|c|}
\hline \multirow{4}{*}{$\begin{array}{l}\text { Çalışma Ortamının } \\
\text { Niteliği }\end{array}$} & 1 aydan az(1) & 91 & 5.30 & 1.76 & G.A & 3 & 9.538 & $.000^{*}$ & \multirow{4}{*}{$4>1,2,3$} \\
\hline & 1-6 ay(2) & 250 & 5.64 & 1.22 & G.İ & 596 & & & \\
\hline & 6 ay-1 yll(3) & 109 & 5.65 & 1.36 & Toplam & 599 & & & \\
\hline & 1 yıldan fazla(4) & 150 & 6.16 & .92 & & & & & \\
\hline \multirow{4}{*}{$\begin{array}{l}\text { Spor Eğitmenlr } \\
\text { Niteliği }\end{array}$} & 1 aydan az(1) & 91 & 5.46 & 1.77 & G.A & 3 & 14.654 & $.000^{*}$ & \multirow{4}{*}{$\begin{array}{l}3>1 \\
4>1,2,3\end{array}$} \\
\hline & $1-6$ ay(2) & 250 & 5.83 & 1.14 & G.İ & 596 & & & \\
\hline & 6 ay-1 yll(3) & 109 & 6.06 & 1.02 & Toplam & 599 & & & \\
\hline & 1 yıldan fazla(4) & 150 & 6.42 & .72 & & & & & \\
\hline \multirow{4}{*}{ Ayrılma İsteği } & 1 aydan az(1) & 91 & 4.85 & 1.51 & G.A & 3 & .388 & .762 & \multirow{4}{*}{ - } \\
\hline & 1-6 ay(2) & 250 & 5.00 & 1.49 & G.İ & 596 & & & \\
\hline & 6 ay-1 yıl(3) & 109 & 4.89 & 1.43 & Toplam & 599 & & & \\
\hline & 1 ylddan fazla(4) & 150 & 5.03 & 1.69 & & & & & \\
\hline \multirow{4}{*}{ Bağlllık } & 1 aydan az(1) & 91 & 5.29 & 1.65 & G.A & 3 & 10.830 & $.000^{*}$ & \multirow{4}{*}{$4>1,2,3$} \\
\hline & $1-6$ ay(2) & 250 & 5.18 & 1.22 & G.İ & 596 & & & \\
\hline & 6 ay-1 yll(3) & 109 & 5.38 & 1.06 & Toplam & 599 & & & \\
\hline & 1 yıldan fazla $(4)$ & 150 & 5.91 & 1.16 & & & & & \\
\hline
\end{tabular}

Tablo 9 incelendiğinde; üyelik süresi değişkenine göre Spor İşletmeleri Müşteri Memnuniyeti Ölçeği gelişim, yönetim, çalışma ortamının niteliği, spor eğitmenleri niteliği ve bağlılık alt boyutları puan ortalaması arasında istatistiksel olarak anlamlı farklar tespit edilmiştir ( $p<.05)$.

Gelişim boyutunda üyelik süresi 6 ay- 1 yıl arası ile 1 yıldan fazla olan katılımcların üyelik süresi 1 aydan az ve 1-6 ay arası olan katılımclara göre yararlandıkları spor işletmelerinden memnuniyet düzeyleri daha yüksek seviyededir.

Yönetim boyutunda üyelik süresi 6 ay-1 yıl arası olan katılımclların üyelik süresi 1 aydan az olan katılımclara göre ve üyelik süresi 1 yıldan fazla olan katılımcların üyelik süresi 1 aydan az ve 1-6 ay arası olan katılımcilara göre yararlandıkları spor işletmelerinden memnuniyet düzeyleri daha yüksek seviyededir.

Hizmetler boyutunda üyelik süresi 1 aydan az olan katılımcların üyelik süresi 6 ay-1 yıl arası olan katılımcılara göre yararlandıkları spor işletmelerinden memnuniyet düzeyleri daha yüksek seviyededir.

Çalışma ortamının niteliği ve bağllıık boyutlarında üyelik süresi 1 yıldan fazla olan katılımcların üyelik süresi 1 aydan az, 1-6 ay ve 6 ay-1 yıl arası olan katılımclara göre yararlandıkları spor işletmelerinden memnuniyet düzeyleri daha yüksek seviyededir.

Spor eğitmenleri niteliği boyutunda üyelik süresi 6 ay-1 yıl arası olan katılımcların üyelik süresi 1 aydan az olan katılımcılara göre ve üyelik süresi 1 yıldan fazla olan katılımcların üyelik süresi 1 aydan az, 1-6 ay ve 6 ay-1 yıl 
arası olan katılımcılara göre yararlandıkları spor işletmelerinden memnuniyet düzeyleri daha yüksek seviyededir.

Fark görülen neredeyse tüm alt boyutlarda üyelik süresi arttıkça katılımcıların yararlandıkları spor işletmelerinden memnuniyet düzeylerinin de arttığı belirlenmiştir.

Ölçeğe ilişkin diğer alt boyut puan ortalamaları arasında ise istatistiksel olarak herhangi bir anlamlı fark tespit edilmemiştir ( $\mathrm{p}>$.05).

Tablo 10'da yararlanılan spor tesisinin türü değişkenine göre Spor İşletmeleri Müşteri Memnuniyeti Ölçeği alt boyutları puan ortalaması Anova Analizi bulgularına yer verilmiştir.

Tablo 10. Yararlanılan spor tesisinin türü değişkenine göre spor işletmeleri müşteri memnuniyeti ölçeği alt boyutları puan ortalaması Anova analizi bulguları

\begin{tabular}{|c|c|c|c|c|c|c|c|c|c|}
\hline & Grup & $\mathbf{N}$ & $\overline{\mathbf{x}}$ & ss & Var. K. & sd & $\mathbf{F}$ & $p$ & Fark \\
\hline \multirow{8}{*}{ Gelişim } & Yüzme havuzu(1) & 78 & 5.82 & .97 & G.A & 7 & \multirow{8}{*}{2.694} & \multirow{8}{*}{$.009 *$} & \multirow{8}{*}{$1>3$} \\
\hline & Fitness(2) & 162 & 5.54 & 1.20 & G.İ & 592 & & & \\
\hline & $\begin{array}{l}\text { Plates/Step-Aero- } \\
\text { bik/Zumba(3) }\end{array}$ & 75 & 5.14 & 1.29 & Top & 599 & & & \\
\hline & Halı saha(4) & 45 & 5.78 & 1.24 & & & & & \\
\hline & Tenis kortu(5) & 4 & 5.22 & .62 & & & & & \\
\hline & Stadyum(6) & 108 & 5.62 & 1.08 & & & & & \\
\hline & Spor salonu(7) & 111 & 5.30 & 1.44 & & & & & \\
\hline & Diğer(8) & 17 & 5.71 & 1.53 & & & & & \\
\hline \multirow{8}{*}{$\begin{array}{l}\text { Prog- } \\
\text { ram }\end{array}$} & Yüzme havuzu(1) & 78 & 5.75 & 1.08 & G.A & 7 & \multirow{8}{*}{2.722} & \multirow{8}{*}{$.009 *$} & \multirow{8}{*}{$\begin{array}{l}1,2,3,4,6 \\
, 7>5\end{array}$} \\
\hline & Fitness(2) & 162 & 5.81 & 1.27 & G.I & 592 & & & \\
\hline & $\begin{array}{l}\text { Plates/Step-Aero- } \\
\text { bik/Zumba(3) }\end{array}$ & 75 & 5.34 & 1.41 & Top & 599 & & & \\
\hline & Halı saha(4) & 45 & 5.56 & 1.16 & & & & & \\
\hline & Tenis kortu(5) & 4 & 4.25 & .28 & & & & & \\
\hline & Stadyum(6) & 108 & 5.66 & 1.05 & & & & & \\
\hline & Spor salonu(7) & 111 & 5.41 & 1.21 & & & & & \\
\hline & Diğer(8) & 17 & 5.26 & 1.30 & & & & & \\
\hline \multirow{13}{*}{$\begin{array}{l}\text { Yöne- } \\
\text { tim }\end{array}$} & Yüzme havuzu(1) & 78 & 6.10 & 1.09 & G.A & 7 & \multirow{8}{*}{1.937} & \multirow{8}{*}{.062} & \multirow{8}{*}{-} \\
\hline & Fitness(2) & 162 & 5.85 & 1.31 & G.I & 592 & & & \\
\hline & $\begin{array}{l}\text { Plates/Step-Aero- } \\
\text { bik/Zumba(3) }\end{array}$ & 75 & 5.48 & 1.62 & Top & 599 & & & \\
\hline & Halı saha(4) & 45 & 6.00 & 1.33 & & & & & \\
\hline & Tenis kortu(5) & 4 & 5.50 & 1.73 & & & & & \\
\hline & Stadyum(6) & 108 & 5.94 & 1.19 & & & & & \\
\hline & Spor salonu(7) & 111 & 5.67 & 1.47 & & & & & \\
\hline & Diğer(8) & 17 & 6.32 & 1.49 & & & & & \\
\hline & Yüzme havuzu(1) & 78 & 4.79 & 1.40 & G.A & 7 & \multirow{5}{*}{2.581} & \multirow{5}{*}{$.013^{*}$} & \multirow{5}{*}{$2>8$} \\
\hline & Fitness(2) & 162 & 5.04 & 1.40 & G.I & 592 & & & \\
\hline & $\begin{array}{l}\text { Plates/Step-Aero- } \\
\text { bik/Zumba(3) }\end{array}$ & 75 & 4.35 & 1.68 & Top & 599 & & & \\
\hline & Halı saha(4) & 45 & 4.60 & 1.60 & & & & & \\
\hline & Tenis kortu(5) & 4 & 4.18 & .37 & & & & & \\
\hline
\end{tabular}




\begin{tabular}{|c|c|c|c|c|c|c|c|c|c|}
\hline \multirow{3}{*}{$\begin{array}{l}\text { Hiz- } \\
\text { metler }\end{array}$} & Stadyum(6) & 108 & 4.59 & 1.38 & & & & & \\
\hline & Spor salonu(7) & 111 & 4.62 & 1.60 & & & & & \\
\hline & Diğer(8) & 17 & 4.00 & 1.81 & & & & & \\
\hline \multirow{8}{*}{$\begin{array}{l}\text { Dona- } \\
\text { nim }\end{array}$} & Yüzme havuzu(1) & 78 & 5.01 & 1.32 & G.A & 7 & \multirow{8}{*}{4.118} & \multirow{8}{*}{$.000^{*}$} & \multirow{8}{*}{$2>1,3,7$} \\
\hline & Fitness(2) & 162 & 5.68 & 1.11 & G.İ & 592 & & & \\
\hline & $\begin{array}{l}\text { Plates/Step-Aero- } \\
\text { bik/Zumba(3) }\end{array}$ & 75 & 5.05 & 1.31 & Top & 599 & & & \\
\hline & Halı saha(4) & 45 & 5.27 & 1.54 & & & & & \\
\hline & Tenis kortu(5) & 4 & 5.09 & .83 & & & & & \\
\hline & Stadyum(6) & 108 & 5.40 & 1.21 & & & & & \\
\hline & Spor salonu(7) & 111 & 5.13 & 1.46 & & & & & \\
\hline & Diğer(8) & 17 & 4.53 & 1.83 & & & & & \\
\hline \multirow{8}{*}{$\begin{array}{l}\text { Çalışma } \\
\text { Ortamı- } \\
\text { nın } \\
\text { Niteliği }\end{array}$} & Yüzme havuzu(1) & 78 & 5.85 & 1.23 & G.A & 7 & \multirow{8}{*}{1.699} & \multirow{8}{*}{.107} & \multirow{8}{*}{ - } \\
\hline & Fitness(2) & 162 & 5.94 & 1.06 & G.İ & 592 & & & \\
\hline & $\begin{array}{l}\text { Plates/Step-Aero- } \\
\text { bik/Zumba(3) }\end{array}$ & 75 & 5.65 & 1.23 & Top & 599 & & & \\
\hline & Halı saha(4) & 45 & 5.68 & 1.54 & & & & & \\
\hline & Tenis kortu(5) & 4 & 5.45 & 1.35 & & & & & \\
\hline & Stadyum(6) & 108 & 5.69 & 1.27 & & & & & \\
\hline & Spor salonu(7) & 111 & 5.42 & 1.56 & & & & & \\
\hline & Diğer(8) & 17 & 5.60 & 1.53 & & & & & \\
\hline \multirow{8}{*}{$\begin{array}{l}\text { Spor } \\
\text { Eğit- } \\
\text { menlr } \\
\text { Niteliği }\end{array}$} & Yüzme havuzu(1) & 78 & 6.13 & 1.18 & G.A & 7 & 1.316 & .240 & \multirow{8}{*}{ - } \\
\hline & Fitness(2) & 162 & 6.00 & 1.01 & G.İ & 592 & & & \\
\hline & $\begin{array}{l}\text { Plates/Step-Aero- } \\
\text { bik/Zumba(3) }\end{array}$ & 75 & 5.89 & 1.21 & Top & 599 & & & \\
\hline & Halı saha(4) & 45 & 6.06 & 1.34 & & & & & \\
\hline & Tenis kortu(5) & 4 & 5.22 & 1.74 & & & & & \\
\hline & Stadyum(6) & 108 & 6.06 & 1.09 & & & & & \\
\hline & Spor salonu(7) & 111 & 5.72 & 1.44 & & & & & \\
\hline & Diğer(8) & 17 & 6.11 & 1.16 & & & & & \\
\hline \multirow{8}{*}{$\begin{array}{l}\text { Ay- } \\
\text { rilma } \\
\text { İsteği }\end{array}$} & Yüzme havuzu(1) & 78 & 4.29 & 1.59 & G.A & 7 & \multirow{8}{*}{3.834} & \multirow{8}{*}{$.000^{*}$} & \multirow{8}{*}{$2,6>1$} \\
\hline & Fitness(2) & 162 & 5.10 & 1.54 & G.İ & 592 & & & \\
\hline & $\begin{array}{l}\text { Plates/Step-Aero- } \\
\text { bik/Zumba(3) }\end{array}$ & 75 & 5.09 & 1.35 & Top & 599 & & & \\
\hline & Halı saha(4) & 45 & 5.10 & 1.59 & & & & & \\
\hline & Tenis kortu(5) & 4 & 5.12 & 1.29 & & & & & \\
\hline & Stadyum(6) & 108 & 5.26 & 1.39 & & & & & \\
\hline & Spor salonu(7) & 111 & 4.72 & 1.60 & & & & & \\
\hline & Diğer(8) & 17 & 5.51 & 1.29 & & & & & \\
\hline \multirow{8}{*}{ Bağlllık } & Yüzme havuzu(1) & 78 & 5.30 & 1.23 & G.A & 7 & \multirow{8}{*}{1.815} & \multirow{8}{*}{.082} & \multirow{8}{*}{ - } \\
\hline & Fitness(2) & 162 & 5.42 & 1.33 & G.İ & 592 & & & \\
\hline & $\begin{array}{l}\text { Plates/Step-Aero- } \\
\text { bik/Zumba(3) }\end{array}$ & 75 & 5.27 & 1.19 & Top & 599 & & & \\
\hline & Halı saha(4) & 45 & 5.76 & 1.30 & & & & & \\
\hline & Tenis kortu(5) & 4 & 5.20 & 1.38 & & & & & \\
\hline & Stadyum(6) & 108 & 5.61 & 1.11 & & & & & \\
\hline & Spor salonu(7) & 111 & 5.20 & 1.41 & & & & & \\
\hline & Diğer(8) & 17 & 5.90 & 1.50 & & & & & \\
\hline
\end{tabular}


Tablo 10 incelendiğinde; yararlanılan spor tesisinin türü değişkenine göre Spor İşletmeleri Müşteri Memnuniyeti Ölçeği gelişim, program, hizmetler, donanım ve ayrılma isteği alt boyutları puan ortalaması arasında istatistiksel olarak anlamlı farklar tespit edilmiştir ( $\mathrm{p}<.05)$.

Gelişim boyutunda yararlanılan spor tesisinin türü yüzme havuzu olan katılımcların yararlanılan spor tesisinin türü plates/step-aerobik/zumba olan katılımclara göre yararlandıkları spor işletmelerinden memnuniyet düzeyleri daha yüksek seviyededir.

Program boyutunda yararlanılan spor tesisinin türü yüzme havuzu, fitness, plates/step-aerobik/zumba, halı saha, stadyum, spor salonu ve diğer olan katılımcıların yararlanılan spor tesisinin türü tenis kortu olan katılımcllara göre yararlandıkları spor işletmelerinden memnuniyet düzeyleri daha yüksek seviyededir.

Hizmetler boyutunda yararlanılan spor tesisinin türü fitness olan katılımcıların yararlanılan spor tesisinin türü diğer olan katılımcılara göre yararlandıkları spor işletmelerinden memnuniyet düzeyleri daha yüksek seviyededir.

Donanım boyutunda yararlanılan spor tesisinin türü fitness olan katılımcıların yararlanılan spor tesisinin türü yüzme havuzu, plates/step-aerobik/zumba ve spor salonu olan katılımcılara göre yararlandıkları spor işletmelerinden memnuniyet düzeyleri daha yüksek seviyededir.

Ayrılma isteği boyutunda yararlanılan spor tesisinin türü fitness ve stadyum olan katılımcıların yararlanılan spor tesisinin türü yüzme havuzu olan katılımclara göre yararlandıkları spor işletmelerinden memnuniyet düzeyleri daha yüksek seviyededir.

Ölçeğe ilişkin diğer alt boyut puan ortalamaları arasında ise istatistiksel olarak herhangi bir anlamlı fark tespit edilmemiştir ( $\mathrm{p}>$.05).

\section{Tartışma ve Sonuç}

Mevcut araştırma bulguları incelendiğinde; cinsiyet değişkenine göre Spor İşletmeleri Müşteri Memnuniyeti Ölçeği yönetim, hizmetler ve spor eğitmenleri niteliği alt boyutları puan ortalaması arasında istatistiksel olarak anlamlı bir farklar tespit edilmiştir $(\mathrm{p}<.05)$. Kadınların yönetimden ve spor eğitmenleri niteliğinden memnun kalma düzeylerinin erkeklere göre daha yüksek seviyede olduğu belirlenirken, hizmet boyutunda memnun kalma düzeylerinin ise erkeklere göre daha düşük seviyede olduğu belirlenmiştir. Kadınların 
yapıları gereği daha titiz, irdeleyici ve hassas oldukları göz önünde bulundurulacak olursa müşterisi oldukları spor işletmelerinde yeterli bilgilendirme ve yönlendirmelerin yapıldığı, bir sorun yaşadıklarında ise kime ve nasıl iletecekleri konusunda yönetime kolay ulaşabildikleri verdikleri yanıtlar sonucunda tespit edilmiştir. Yönetimin bilgilendirme yapıp yapmaması erkeklerin memnun kalma düzeylerine engel teşkil etmediği düşünülerek bu konuda daha rahat oldukları ve bu sebeple kadınlara oranla daha düşük çıtığ söylenebilir. Ayrıca kadınların hizmet alırken erkeklere oranla spor eğitmenlerinin nazik, saygıll, deneyimli, güvenilir, adil, samimi, motive edici, müşterilere yardım için istekliliği ve gelişimlerini yakından takip ediyor oluşları gibi detaylara daha çok dikkat etmeleri (McDonald vd., 1995) o işletmeden memnun kalmaları için yeterli ve önemli bir sebep olduğu söylenebilir. Fakat kadınların erkeklere oranla müşterisi oldukları spor işletmelerindeki spor programlarını, yan hizmetleri (yeme-içme, çocuk bakımı vb.), acil durum ve güvenlik önlemlerini, diğer aktivite unsurlarını (sauna, masaj salonu, TV odası vb.)yeterli çeşitlilikte bulmadıkları için hizmetler alt boyutunda daha düşük memnuniyete sahip oldukları söylenebilir.

Yıldırım'ın (2018) yapmış olduğu çalışmada cinsiyete göre spor tesisleri müşteri memnuniyeti alt boyutları ortalama puanları incelendiğinde kadınların erkeklere oranla genel olarak memnuniyet düzeylerinin daha yüksek olduğu istatistiksel olarak tespit edilmiştir. Süllüoğlu'nun (2018) yapmış olduğu çalışmada kadınların erkeklere oranla tesislerden memnun olma düzeylerinin istatistiksel olarak oldukça yüksek olduğu tespit edilmiştir. Şahin' in (2018) yapmış olduğu çalışmada kadınların erkeklere oranla memnuniyet düzeylerinin yüksek olduğu belirlenmiştir. Sabırlı'nın (2018) yapmış olduğu çalışmada cinsiyet değişkenine göre kadın üyelerin erkek üyelere oranla daha memnun oldukları tespit edilmiştir. Ceyhun'un (2006) yapmış olduğu çalışmada kadınların erkeklere oranla memnuniyet düzeylerinin yüksek olduğu belirlenmiştir. Memiş ve Ekenci'nin (2007) yapmış olduğu çalışmada, kadın müşterilerin erkek müşterilere oranla tesislerin fiziksel ortamını beğendikleri ve hizmet kalitesinden memnuniyete yönelik maddelere ise yine kadın müşterilerin daha olumlu cevaplar verdikleri tespit edilmiştir. Memiş'in (2002) yapmış olduğu çalışmada müşterilerin cinsiyetlerine ilişkin bulgular incelendiğinde kadın müşterilerin memnuniyet düzeylerinin erkek müşterilere oranla daha yüksek olduğu tespit edilmiştir. Alexandris ve Pali- 
alia (1999)'nın Yunanistan'da yapmış oldukları çalışmada fitness merkezlerine üye olan kadın müşterilerin erkek müşterilere oranla memnuniyet düzeylerinin daha yüksek seviyede olduğu tespit edilmiştir. Bu sonuçlar mevcut çalışma sonuçlarını destekler niteliktedir.

Bulut'un (2019) yapmış olduğu çalışmada müşteri memnuniyeti ile cinsiyet değişkeni arasında herhangi bir anlamlı ilişki tespit edilmemiştir. Yıldız, Duyan ve Günel'in (2018) yapmış olduğu çalışmada müşteri memnuniyeti ile cinsiyet değişkeni arasında herhangi bir anlamlı ilişki görülmemiştir. Üzüm vd.'nin (2016) yapmış olduğu çalışmada, kadınların hizmet kalitesi algı düzeyinin erkeklere göre daha düşük olduğu tespit edilmiştir. Erdoğan'ın (2016) yapmış olduğu çalışmada erkek müşterilerin memnuniyet düzeylerinin kadın müşterilerden daha yüksek olduğu tespit edilmiştir. Göksel'in (2012) yapmış olduğu çalışmada müşterilerin cinsiyetlerine ilişkin bulgular incelendiğinde erkek müşterilerin memnuniyet düzeylerinin kadın müşterilere oranla daha yüksek olduğu tespit edilmiştir. Yıldız ve Tüfekçi'nin (2010) yapmış oldukları çalışmada, kadınların hizmet kalitesi algılarının erkeklerden daha düşük olduğuna yönelik sonuçlar tespit edilmiştir. Theodorakis vd.'nin (2004) Portekiz'deki spor kulüplerinde müşteri memnuniyetini ölçmek ve demografik unsurlarla karşılaştırmak amacıyla yaptıkları araştırma bulgularında ise erkeklerin kadınlara oranla memnuniyet düzeylerinin yüksek olduğu tespit edilmiştir. Kim ve Kim'in (1995) yapmış oldukları çalışmada, kadınların hizmet kalitesi algılarının erkeklerden daha düşük olduğuna yönelik sonuçlar tespit edilmiştir. Tüm bu çalışma sonuçları ile mevcut çalışma sonuçları farklılık göstermektedir.

Yaş değişkenine göre Spor İşletmeleri Müşteri Memnuniyeti Ölçeği program, hizmetler ve ayrılma isteği alt boyutları puan ortalamaları arasında istatistiksel olarak anlamlı bir fark tespit edilmiştir $(\mathrm{p}<.05)$. Program boyutunda yaş ilerledikçe memnuniyet düzeylerinin düştüğü, hizmetler boyutunda yaş ile doğru orantılı olarak yaş ilerledikçe memnuniyet düzeylerinin arttı̆̆ 1 ve ayrılma isteği boyutunda ise yaş ilerledikçe katılımcıların ayrılma isteklerinin de arttı̆̆ tespit edilmiştir. Yaşı küçük olan katılımcıların yaşı büyük olan katılımclara oranla hizmetler boyutundan daha az memnun oldukları görülürken program boyutundan daha fazla memnun oldukları ve yararlanmakta oldukları spor işletmesinden ayrılma isteklerinin olmadığı görülmüştür. Yaş ilerledikçe düzene, dakikliğe, planlılığa daha çok anlam yükledikleri, zaman 
yönetimi konusunda daha hassas oldukları ve daha profesyonel bir yaklaşıma sahip olmaları yönünden program boyutundan memnun olmadıkları ve ayrılma isteğinde oldukları düşünülmektedir. Genç katılımcıların ise sportif faaliyetlerde bulunurken üyesi oldukları spor işletmelerindeki hizmetlerin motivasyonların daima yüksek tutacak, istek ve ihtiyaçlarına anında cevap verecek yüksek bir beklenti içerisinde olmalarından dolayı memnuniyet düzeylerinin düşük olduğu düşünülmektedir.

Bulut'un (2019) yapmış olduğu çalışmada yaşı büyük olan katılımcıların yaşı küçük olan katılımcılara oranla memnuniyet düzeylerinin daha yüksek olduğu tespit edilmiştir. Yıldırım'ın (2018) yapmış olduğu çalışmada yaşı küçük olan bireylerin yaşı büyük olanlara göre antrenör yaklaşımından, program desteğinden ve tesis atmosferinden daha az memnun oldukları, hijyen yönünden ise daha fazla memnun oldukları tespit edilmiştir. Süllüoğlu'nun (2018) yapmış olduğu çalışmada ise müşteri memnuniyetinin yaşa göre farklılaştı̆̆ tespit edilmiştir. Ceyhun'un (2006) yapmış olduğu çalışmada yaşı küçük olan katılımcıların yaşı büyük olan katılımcılara oranla memnuniyet düzeylerinin daha yüksek olduğu belirlenmiştir. Sevilmiş'in (2015) yapmış olduğu çalışmada yaşı büyük olan katılımcıların yaşı küçük olan katılımcılara oranla memnuniyet düzeylerinin daha yüksek olduğu tespit edilmiştir. Ayrıca Göksel'in (2012) yapmış olduğu çalışmada ise müşteri memnuniyetinin yaşa göre farklılaştığı tespit edilmiştir. Liu vd. (2009)'nın yapmış olduğu çalışmada da aynı nitelikte sonuçlar tespit edilmiştir. Memiş' in (2002) yapmış olduğu çalışmada müşterilerin yaşlarına ilişkin bulgular incelendiğinde yaşı büyük olan müşterilerin memnuniyet düzeylerinin yaşı küçük olan müşterilere oranla daha yüksek olduğu tespit edilmiştir. Ortaya çıkan tüm bu çalışma sonuçları mevcut çalışma sonuçlarını desteklemektedir.

Yıldız, Duyan ve Günel'in (2018) yapmış olduğu çalışmada müşteri memnuniyeti ile yaş değişkeni arasında herhangi bir anlamlı ilişki görülmemiştir. Saraç'ın (2018) yapmış olduğu çalışmada üyelerin yaş gruplarına göre tüm alt ölçeklerin ortalama değerleri arasında istatistiksel olarak anlamlı bir farklılık bulunamamıştır. Şahin'in (2018) yapmış olduğu çalışmada müşteri memnuniyetinde yaş değişkeni açısından istatistiksel olarak anlamlı farklılık görülmemiştir. Yine Üzüm vd. (2016) ve Erdoğan'ın (2016) yapmış olduğu çalışmada müşteri memnuniyetinde yaş değişkeni açısından istatistiksel olarak anlamlı farklılık görülmemiştir. Lapa ve Baştaç (2012), Öztürk, Adiloğul- 
ları ve Ay (2011), Yıldız ve Tüfekçi'nin (2010) ayrı ayrı yapmış oldukları çalışmalarda müşteri memnuniyetinde yaş değişkeni açısından istatistiksel olarak anlamlı farklılık görülmemiştir. Tüm bu çalışma sonuçları ile mevcut çalışma sonuçları farklılık göstermektedir.

Medeni durum değişkenine göre Spor İşletmeleri Müşteri Memnuniyeti Ölçeği alt boyutları puan ortalaması arasında istatistiksel olarak anlamlı bir farklar tespit edilememiştir (p>.05). Evli ve bekar olan katılımcıların spor işletmeleri memnuniyet düzeyleri arasında herhangi bir anlamlı farkın olmadığı görülmüsstür. Bu bulgunun oluşmasında evlilik ile beraber bireyin günlük yaşamındaki ihtiyaç ve beklentilerinin değişmediği ve dolayısı ile algılarının sabit kaldığı düşünülmekle birlikte memnuniyet düzeyi için medeni durum değişkeninin belirleyici bir kriter olmadığı da söylenebilir.

Bulut'un (2019) yapmış olduğu çalışmada müşteri memnuniyeti ile medeni durum değişkeni arasında herhangi bir anlamlı ilişki tespit edilememiştir. Şahin'in (2018) ve Erdoğan'ın (2016) yapmış olduğu çalışmalarda müşteri memnuniyetinde medeni durum değişkeni açısından istatistiksel olarak anlamlı farklılık görülmemiştir. Yine Ceyhun'un (2006) yapmış olduğu çalışmada müşteri memnuniyetinde medeni durum değişkeni açısından istatistiksel olarak anlamlı farklılık görülmemiştir. Erdoğan'ın (2016) yapmış olduğu çalışmada müşteri memnuniyetinde medeni durum değişkeni açısından istatistiksel olarak anlamlı farklılık görülmemiştir. Ortaya çıkan tüm bu çalışma sonuçları mevcut çalışma sonuçlarını desteklemektedir.

Saraç'ın (2018) yapmış olduğu çalışmada evli bireylerin bekar bireylere oranla daha çok benimsedikleri görülmüştür. Süllüoğlu'nun (2018) yapmış olduğu çalışmada evli olan katılımcıların tesislerden memnuniyet düzeylerinin bekarlara oranla daha yüksek olduğu ortaya çıkmıştır. Üzüm vd.'nin (2016) yapmış olduğu çalışmada, evli olan katılımcıların hizmet kalitesi algı düzeylerinin bekar üyelere göre daha yüksek olduğu tespit edilmiştir. Sevilmiş' in (2015) yapmış olduğu çalışmada evli olan üyelerin bekar üyelere göre genel memnuniyet düzeylerinin daha yüksek olduğu tespit edilirken Yüzgenç ve Özgül'ün (2014) yapmış oldukları çalışmalarda, evli olan katılımcların hizmet kalitesi algı düzeylerinin bekar üyelere göre daha yüksek olduğu tespit edilmiştir. Bayrak'ın (2013) yapmış olduğu çalışmada bekar üyelerin memnuniyet düzeylerinin evli üyelerden daha fazla olduğu tespit edilmiştir. Öztürk, Adiloğulları ve Mungan Ay (2011) yaptığı çalışmada Sağlıklı Yaşam ve Spor Merkezi müşterilerinin tatmin düzeyleri alt boyutları ortalamalarının 
medeni durum değişkenine göre evli müşterin lehine anlamlı bir fark bulunmuştur. Yine Ergin vd. (2010), Gençer vd. (2008), Memiş'in (2002) yapmış olduğu çalışmada müşterilerin medeni durumlarına ilişkin bulgular incelendiğinde evli olan müşterilerin memnuniyet düzeylerinin bekar olan müşterilere oranla daha yüksek olduğu tespit edilmiştir. Tüm bu çalışma sonuçları ile mevcut çalışma sonuçları farklılık göstermektedir.

Aylık gelir düzeyi değişkenine göre Spor İşletmeleri Müşteri Memnuniyeti Ölçeği gelişim, program, yönetim, spor eğitmenleri niteliği, ayrılma isteği ve bağlılık alt boyutları puan ortalaması arasında istatistiksel olarak anlamlı bir farklar tespit edilmiştir ( $\mathrm{p}<.05)$. Bulgulardan hareketle müşteri memnuniyetinin aylık gelir düzeyine göre farklılaştığı görülmektedir. Genel olarak düşük ve yüksek aylık gelire sahip katılımcıların memnuniyet düzeylerinin daha yüksek olduğu tespit edilmiştir. Aylık geliri düşük olan katılımcıların çoğunluğunu öğrencilerin oluşturduğu düşünüldüğünde spor yapma ve bunu başarmanın vermiş olduğu hazzı yaşama, sportif aktivitelerle yeni bir şeyler öğrenebilme ve bulunduğu ortam içerisinde yeni arkadaşlıklar edinerek sosyalleşmelerinin memnuniyet düzeylerini önemli ölçüde ve olumlu yönde etkilediği söylenebilir. Aylık geliri yüksek olan katılımcıların ise üyesi oldukları spor işletmesinin, beklenti ve ihtiyaçlarını doğru yönde karşıladığ1 düşünülerek memnuniyet düzeylerinin bu yönde yüksek olduğu söylenebilir.

Saraç'ın (2018), Süllüoğlu'nun (2018), Ceyhun'un (2016), Göksel'in (2012) yapmış olduğu çalışmada müşteri memnuniyetinin aylık gelir düzeyine göre farklılaştığı görülmüştür. Bu sonuçlar mevcut çalışma sonuçları ile paralellik gösterirken Bulut'un (2019), Sabırlı'nın (2018), Erdoğan'ın (2016), Sevilmiş'in (2015) ve Memiş' in (2002) ayrı ayrı yapmış oldukları çalışmalarda müşterilerin aylık gelirlerine ilişkin bulgular incelendiğinde aylık gelir arttıkça müşterilerin memnuniyet düzeylerinin de arttığ tespit edilmiştir.

Daha önce bir spor merkezinden yararlanma durumu değişkenine göre Spor İşletmeleri Müşteri Memnuniyeti Ölçeği donanım ve bağlllık alt boyutları puan ortalaması arasında istatistiksel olarak anlamlı bir farklar tespit edilmiştir $(\mathrm{p}<.05)$. Daha önce bir spor merkezinden yararlanmayan katılımciların yararlanan katılımclara göre spor işletmelerinden memnuniyet düzeyleri daha yüksek seviyededir. Bu bulgulardan hareketle daha önce bir spor merkezinden yararlanan bireylerin spor yapma alışkanlığı edinemeyip dolay1sıyla devam ettiremedikleri savunulabilir. Daha önce bir spor merkezinden 
yararlanmayan memnuniyet düzeyleri yüksek olan müşterilerin ise farklı bir ortama girmenin heyecanı ve hevesi, sosyal ortam edinip yeni arkadaşlıklar kurma ve özgüven kazanma gibi nedenlere dayandırılabilir.

Memiş̧' in (2002) yapmış olduğu çalışmada müşterilerin daha önce bir spor tesisinden faydalanma durumuna ilişkin bulgular incelendiğinde daha önce bir spor tesisinden faydalanan müşterilerin daha önce bir spor tesisinden faydalanmayan müşterilere oranla memnuniyet düzeylerinin daha yüksek olduğu tespit edilmiştir. Bu sonuç mevcut çalışma sonucu ile farklılık göstermekte olup ele alınan araştırmaların incelenmesi sonucu mevcut çalışma sonucunu destekleyici bulgulara rastlanmamıştır.

Yararlanmakta olduğunuz spor merkezi değişkenine göre Spor İşletmeleri Müşteri Memnuniyeti Ölçeği gelişim, program, hizmetler ve çalışma ortamının niteliği alt boyutları puan ortalaması arasında istatistiksel olarak anlamlı bir farklar tespit edilmiştir ( $\mathrm{p}<.05)$. Gelişim, program, hizmetler ve çalışma ortamının niteliği boyutlarında yararlanmakta olduğunuz spor merkezi değişkenine ‘özel işletme' yanıtı veren katılımcların 'kamu işletmesi' yanıtı veren katılımcılara göre yararlandıkları spor işletmelerinden memnuniyet düzeyleri daha yüksek seviyededir. Özel spor işletmelerinin lehine olan bu farkın, özel işletmelerin ticari kaygı ve kar amacı gütmeleri nedeni ile müşterilerinin ihtiyaçlarına kamu işletmelerine oranla daha fazla önem vermelerinden kaynaklandığı savunulabilir. Ticari kaygı gütmeyen kamu sektöründe hizmet veren spor işletmelerinin ise gelişim, program, hizmetler ve çalışma ortamının nitelikliliği konusunda sürekli olarak kendini yenilemesi ve mevcut memnuniyet düzeyini artırmaya yönelik tedbirler alarak özel spor kurumları ile rekabet edecek düzeye getirilmesinin önemli bir gereklilik olacağı savunulabilir. Bir spor işletmesinin verimliliği açısından en önemli faktörlerden biri olan açılış ve kapanış saatleri, en çok özel spor merkezlerindeki müşterileri memnun etmekte olduğu ve bu durumun da kamuya ait spor işletmelerinde genel bir sorun oluşturduğu düşünülmektedir.

Uslu, Polat ve Üzüm (2018), Üzüm vd. (2016), Bıyıklı (2007) ile Boz'un (2007) yapmış oldukları çalışmalarda, özel spor merkezlerinin ortalamasının kamu kurumlarına ait merkezlerden daha yüksek olduğu tespit edilmiştir. Memiş ve Ekenci (2007) ile Memiş'in (2002) yapmış olduğu çalışmalarda müşterilerin faydalandıkları tesise ilişkin bulgular incelendiğinde özel spor tesislerinden faydalanan müşterilerin memnuniyet düzeylerinin kamu spor 
tesislerinden faydalanan müşterilere oranla daha yüksek olduğu tespit edilmiştir. Bu sonuçlar mevcut çalışma sonuçlarını desteklemektedir.

Üyelik süresi değişkenine göre Spor İşletmeleri Müşteri Memnuniyeti Ölçeği gelişim, yönetim, hizmetler, çalışma ortamının niteliği, spor eğitmenleri niteliği ve bağlılık alt boyutları puan ortalaması arasında istatistiksel olarak anlamlı bir farklar tespit edilmiştir ( $\mathrm{p}<.05)$. Üyelik süresi fazla olan katılımc1ların üyelik süresi daha az olan katılımcilara oranla hizmetler boyutundan daha az memnun oldukları görülürken gelişim, yönetim, çalışma ortamının niteliği, spor eğitmenleri niteliği ve bağllılı boyutlarından daha fazla memnun oldukları görülmüştür. Üyelik süresi fazla olan katılımcılar sadık müşteri profili yaratmakla birlikte üyesi oldukları spor işletmelerini daha çok benimsedikleri için sportif etkinliklerde bulundukları ortamın artık tüm ihtiyaçlarını karşılayabilir olmasını umdukları ve buna bağlı olarak daha fazla beklenti içerisinde oldukları düşünülmektedir. Fakat bu uzun üyelik sürecinde verdikleri cevaplar doğrultusunda benimseyip bağlandıkları spor işletmelerinden yeterli doyuma ulaştıkları söylenebilir. Üyelik süresi artıkça memnuniyetin de beraberinde artması, bu işletmelerin müşteri tutundurma, müşteri ilgi ve ihtiyaçlarına yönelik hizmet sunma konusunda teknolojiyi takip ederek kalite standartlarını yakaladığının ve bu standartlarda devamlılık sağlayarak kontrollü çalışmalar yaptığının, müşterilerinin bağlllıklarına ve tatminlerine önem verdiğinin kaçınılmaz bir göstergesidir.

Bulut'un (2019) yapmış olduğu çalışmada müşterilerin üyelik süreleri arttıkça memnuniyet düzeylerinin de arttığ1 tespit edilmiştir. Memiş'in (2002) yapmış olduğu çalışmada müşterilerin tesisten faydalanma sürelerine ilişkin bulgular incelendiğinde tesisten faydalanma süreleri arttıkça müşterilerin memnuniyet düzeylerinin de arttı̆̆ tespit edilmiştir. Bu çalışma sonuçları ile mevcut çalışma sonuçlarını desteklemektedir.

Yıldırım'ın (2018) yaptı̆̆ çalışmada fark görülen alt boyutlarda genel olarak üyelik süresi arttıkça memnuniyet düzeylerinin azaldığı bir durum tespit edilmiştir. Süllüoğlu'nun (2018) yapmış olduğu çalışmada müşteri memnuniyetinin tesis kullanım süresi düzeyine göre farklılaştığı görülmekle birlikte uzun süredir tesise üye olan kişilerin tesiste sunulan hizmetlerden daha az memnuniyet duyduğu tespit edilirken yine Sabırlı'nın (2018) yapmış olduğu çalışmada da müşterilerin üyelik süreleri arttıkça memnuniyet düzeylerinin azaldığı tespit edilmiştir. Saraç'ın (2018) yapmış olduğu çalışmaya katılan 
üyelerin spora başlama sürelerine göre yapılan istatistik sonuçlarında herhangi anlamlı bir farklılık bulunamamakla birlikte Şahin'in (2018) yapmış olduğu çalışmada müşteri memnuniyetinde üyelik süresi değişkeni açısından istatistiksel olarak anlamlı farklılık görülmemiştir. Ceyhun'un (2016) yapmış olduğu çalışmada müşterilerin tesisten faydalanma süreleri arttıkça memnuniyet düzeylerinin azaldığ 1 tespit edilirken Sevilmiş (2015) ve Yüzgenç'in (2010) yapmış oldukları çalışmalarda müşteri memnuniyetinde üyelik süresi değişkeni açısından istatistiksel olarak anlamlı farklılık görülmemiştir. Tüm bu çalışma sonuçları ile mevcut çalışma sonuçları farklılık göstermektedir.

Yararlanılan spor tesisinin türü değişkenine göre Spor İşletmeleri Müşteri Memnuniyeti Ölçeği gelişim, program, hizmetler, donanım ve ayrılma isteğ alt boyutları puan ortalaması arasında istatistiksel olarak anlamlı bir farklar tespit edilmiştir $(p<.05)$. Genel olarak fark görülen tüm alt boyutlarda yararlanılan spor tesisinin türü yüzme havuzu, ve fitness olan katılımcıların yararlandıkları spor işletmelerinden memnuniyet düzeylerinin daha yüksek seviyede olduğu belirlenmiştir. Bu sonuçlardan hareketle yüzme havuzunda suyun sakinlik ve dinginlik verdiği, insanı rahatlattığı düşünülerek kalori yaktırma ve kas çalıştırma aracı olarak daha çok tercih edildiği ve memnuniyetinin daha yüksek çıktığı düşünülmektedir. Son yıllarda "fit olmanın" medya, eğitim ve sağlık sektörlerince desteklenen bir kavram olması nedeniyle insanları fitness konusunda algıda seçici bir hale bürümüştür. Popüler bir etkinlik haline gelen fitness, insanlar tarafından büyük bir ilgi görmeye başlamıştır (Güdül, 2008). Değişken ve sağlıksız hava koşullarından etkilenmeden, işin uzmanları ile çalışıyor olma düşünceleri, istenilen fit bir vücut için yapılması gereken aletli hareket egzersizleri için gerekli aletleri alma ihtiyacına gerek kalmadan istenilen alet ile çalışılabilmeleri ve bu egzersizleri disiplinli ve düzenli bir şekilde olayın ciddiyetini kavrayarak yapmaları vb. birçok nedenlerle tesis türü fitness olan katılımcıların memnuniyet düzeylerinin daha yüksek çıktığı düşünülmektedir.

Sonuç olarak spor işletmelerinden yararlanan üyelerin genellikle müşteri memnuniyetlerinin yeterli olduğu düşünülmektedir. Araştırma esnasında dikkat çekici bir konu ise hizmet sektöründeki işletmelerde müşteri memnuniyeti ile ilgili araştırmalar var olsa da spor işletmelerine yönelik müşterilerin memnuniyetlerini etkileyen etmenlere yönelik literatür eksikliğinin önemli boyutlarda olduğu söylenebilir. Bilimsel çalışmaların, ülkemizde sporun ge- 
lişmesi ve yaygınlaşması açısından önemli oluşu düşünülecek olunursa mevcut çalışma konusu dahil bu alanda yapılması gereken nitelikli birçok bilimsel çalışmalara ihtiyaç duyulduğu düşünülmektedir. Ayrıca bu çalışmadaki veriler sınırlandırılmış spor işletmelerinden elde edildiği için çalışma sonuçları tüm müşterilere genellenemediği ve dolayısıyla elde edilen sonuçların genel olup olmadığını ve farklı örneklem gruplarında tutarlı olup olmadığını ortaya çıkarmak için benzer çalışmalara ihtiyaç duyulduğu düşünülmektedir.

Yapılan bu çalışmada elde edilen bulgular doğrultusunda aşağıdaki önerilere yer verilmiştir.

- Spor işletmelerini kullanan kadın müşterilerin işletmelerin hem yönetiminden hem de spor eğitmenlerinin niteliğinden daha memnun oldukları göz önünde bulundurularak, erkek müşterileri memnun edici yönetime ve spor eğitmenleri niteliğine yönelik çalışmalar yapılmalıdır.

- Hizmet sektöründe kadın müşterilere yönelik spor işletmesi içerisinde yeme-içme, kuaför, kafeterya, çocuk bakım yerleri, solaryum, sauna, masaj salonu, TV odası vb. hizmetlerin bulunması daha çok bireylerin spora katılım yapmasını sağlayabilir.

- Araştırmaya katılan müşterilerin yaşlarına yönelik spor programları düzenlenmeli ve çeşitlendirilmelidir.

- Spor işletmesi ile ilgili yapılması istenen hedef ve eksikliklerin önem sırasına göre belirlenerek çözüm yolları üretilmelidir.

- Spor işletmesi ücretlendirme tarifesinin öğrenci bütçesi göz önünde tutularak öğrenci-yetişkin olarak düzenlenme yapılmalıdır.

- Ulaşım konusunda spor işletmelerine erişilebilirlik desteklenmelidir.

- Üyelerin bireysel farklılıkları, ihtiyaçları ve görüşleri doğrultusunda, spor işletmelerinde fiziki düzenlemeler, modern donanım, personel ve spor eğitmenlerinin davranışları, 1şık ve havalandırma, yeni alet ve ekipman alımı, açılış ve kapanış saatleri gibi düzenleyici adımlar atılmalıdır.

- Faklı illerde ve farklı kültürlerdeki spor işletmeleri müşterileri de hesaba katılarak bu tarz çalışmaların yapılması daha sağlıklı sonuçlar elde edilmesini kolaylaştıracağı bu tarz çalışmalar yaygınlaştırılmalıdir. 
- Müşterilerin düzenli aralıklarla istek ve görüşleri alınarak memnuniyet düzeyleri ölçülmelidir.

- Müşterilerin problem ve şikayetleri ile ilgili geri dönüşlerin zamanında ve eksiksiz yerine getirilmesi için ekstra gayret gösterilmelidir.

- Yeni müşsteriler kazanmak var olan müşteriyi kazanmaktan daha pahalıdır.' sözü spor işletmeleri yöneticileri için bir ilke haline gelmelidir. 
EXTENDED ABSTRACT

\title{
Investigation of Customer Satisfaction in Sports Business According to Some Variables
}

\author{
Sema Uslu - Mehmet Yildirım \\ Yozgat Bozok Üniversitesi
}

The purpose of this research; It is the examination of customer satisfaction in sports businesses according to some variables. The universe of the research consists of the members of the sports businesses in Yozgat in 20192020. The sample of the study consists of 340 women and 260 men, a total of 600 members, who were customers in sports businesses between December 1 and February 28 in the 2019-2020 winter season, selected among sports businesses with the convenience sampling technique.

The questionnaire form used in the study consists of two parts. In the first part, the "Demographic Information Form" was used to determine the personal and social characteristics of the participants, and in the second part, the "Customer Satisfaction Scale in Sports Businesses" developed by Sevilmiş (2015) to determine the satisfaction levels of the participants was used.

The data obtained in the research were transferred to the SPSS 20.0 package program. Before starting the statistical analysis of the data obtained from the research group, it is necessary to prepare the data and make it suitable for analysis. It should be noted that kurtosis and skewness coefficients are important in this process (Şimşek, 2007). If the coefficient of skewness is not greater than 3 and the kurtosis coefficient is not greater than 10, it indicates that the distribution is normal (Kline, 2016). In this study, it was determined that the skewness values of the data obtained regarding the scale were between -0.313 / 2.260 and the kurtosis values between -0.099 / 3.410. According to these results, it was determined that the data showed a normal distribution and parametric tests were used in statistical analysis. Frequency analysis was used to describe the demographic characteristics of the participants in the analysis of the data. T-test, ANOVA analysis and multiple comparison tests (Tukey, Tamhane) accor- 
ding to the homogeneity of the variances were used to determine the differences between the sub-dimensions of the sports facilities customer satisfaction scale according to the variables considered. The statistical significance level in the tests was determined as 0.05 .

As a result of the analysis; According to the gender variable, a statistically significant difference was found between the sub-dimensions of the Sports Business Customer Satisfaction Scale management, services and sports trainers quality $(\mathrm{p}<.05)$. While it was determined that the satisfaction level of women with the management and the qualifications of sports trainers was higher than men, their level of satisfaction in terms of service was lower than men.

According to the age variable, a statistically significant difference was found between the mean scores of the Sports Business Customer Satisfaction Scale program, services and the desire to leave sub-dimensions ( $p$ $<.05)$.

In the program dimension, it was determined that satisfaction levels decrease as age increases, in services dimension, satisfaction levels increase in direct proportion with age, and in the dimension of the desire to leave, the participants' willingness to leave increases as the age increases. While it was observed that younger participants were less satisfied with the service dimension than the older participants, it was observed that they were more satisfied with the program size and did not want to leave the sports business they were benefiting from.

According to the marital status variable, no statistically significant difference was found between the average score of the Sports Business Customer Satisfaction Scale sub-dimensions ( $p>$.05). It was observed that there was no significant difference between the satisfaction levels of the married and single participants in sports businesses.

According to the monthly income level, a statistically significant difference was found between the development, program, management, qualification of sports trainers, desire to leave and commitment sub-dimensions of the Sports Business Customer Satisfaction Scale ( $<<.05)$. Based on the findings, it is seen that customer satisfaction differs according to monthly income level. In general, it was found that the satisfaction levels of the participants with low and high monthly income were higher. 
A statistically significant difference was found between the mean scores of the Sports Enterprises Customer Satisfaction Scale hardware and commitment sub-dimensions according to the variable of benefiting from a sports center previously $(\mathrm{p}<.05)$. Participants who have not used a sports center before have a higher level of satisfaction with sports businesses compared to the participants who have benefited.

According to the sports center variable you are using, a statistically significant difference was found between the sub-dimensions of the Sports Business Customer Satisfaction Scale development, program, services and the quality of the work environment $(\mathrm{p}<.05)$. The satisfaction level of those who benefit from private enterprises is higher than those who benefit from public enterprises.

A statistically significant difference was found between the development, management, services, the quality of the working environment, the quality of sports trainers and the sub-dimensions of commitment according to the variable of membership duration $(\mathrm{p}<.05)$. Participants with a longer period of membership are less satisfied with the service dimension than those with less membership. However, it was observed that they were more satisfied with the dimensions of development, management, the quality of the working environment, the quality of sports trainers and their commitment.

According to the variable of the type of sports facility used, a statistically significant difference was found between the sub-dimensions of the Sports Business Customer Satisfaction Scale development, program, services, equipment and the desire to leave sub-dimensions $(\mathrm{p}<.05)$. In general, it was determined that the sports facilities used in all sub-dimensions where there is a difference are swimming pools and fitness facilities have a higher level of satisfaction with the sports businesses they use.

As a result, it is thought that the customer satisfaction of the members who benefit from sports businesses is generally sufficient. A striking issue during the research is that although there are studies on customer satisfaction in businesses in the service sector, it can be said that the lack of literature on the factors affecting customer satisfaction for sports businesses is significant. If it is considered that scientific studies are important for the development and widespread of sports in our country, it is thought that many qualified scientific studies are needed in this field, including 
the current study subject. In addition, since the data in this study were obtained from limited sports businesses, it is thought that the results of the study could not be generalized to all customers and therefore similar studies are needed to reveal whether the results obtained are general or not in different sample groups.

\section{Kaynakça / References}

Alexandris, A., Palialia, E. (1999). Measuring customer satisfaction in fitness centres in Greece: An exploratory study. Managing Leisure, 4(4), 218- 228.

Bayrak, E. (2013). Sağlıklı yaşam ve spor merkezi müşterilerinin (bayanların) memnuniyet düzeylerinin belirlenmesi. International Journal of Social Science, 6(6), 217-230.

Bıyıkl, H. (2007). Sağllk işletmelerinin kurumsal birleşmelerinin müşsteri memnuniyeti üzerine etkisi. (yayımlanmamıs yüksek lisans tezi). G.Ü. Sosyal Bilimler Enstitüsü. Ankara.

Boz, C. (2007). Yerel yönetimlerin spor tesislerinde toplam kalite yönetimi uygulamalar. (İstanbul Büyükşehir Belediyesi Örneği). (yayımlanmamış yüksek lisans tezi), Marmara Üniversitesi Sağlık Bilimleri Enstitüsü. İstanbul.

Bulut, A. (2019). Alglanan hizmet kalitesi, müşteri memnuniyeti ve müşteri sadakati: fitness merkezi üyeleri üzerinde bir uygulama. (yüksek lisans tezi). Selçuk Üniversitesi, Sağlık Bilimleri Üniversitesi, Konya.

Büyüköztürk, Ş., Kılıç Çakmak, E., Akgün, Ö.E., Karadeniz, Ş. ve Demirel, F. (2014). Bilimsel Araştırma Yöntemleri. Ankara: Pegem Akademi.

Ceyhun, S. (2006). Spor işletmelerinde hizmet kalitesi. (doktora tezi). Gazi Üniversitesi, Sağllk Bilimleri Enstitüsü. Ankara.

Erdoğan, A. (2016). Algllanan hizmet kalitesi, hizmet değeri ve memnuniyet üzerinde alglanan risk faktörünün etkisi: Sağllkl yaşam ve spor merkezleri üzerine bir uygulama. (yüksek lisans tezi). Selçuk Üniversitesi, Sağllk Bilimleri Enstitüsü, Konya.

Ergin, B.M., İmamoğlu, F.A., Tunç, T., Akpınar, S. ve Çon, M. (2010). Üniversite spor merkezlerindeki hizmet kalitesi boyutlarının algı ve önem düzeylerinin incelenmesi. Spor ve Performans Araşttrmalan Dergisi, 2(1), 41-49.

Erkan, M. (1992). Sosyolojik açıdan spor. İstanbul: Kutsun Matbaacllk.

Erkan, N. (1989). Spor tesislerinin planlanmasında kullanıc gereksinimlerinin gözetilmesi, hijyenik ve ergonomik yaklaşımlar. içindeTürkiye'de Spor Tesislerinde Genel Planlama Sorunları, İstanbul: Yıldız Üniversitesi Matbaası. 
Fraenkel, J.R. and Wallen, N.E. (2006). How to design and evaluate research in education (6th Ed.), McGraw-Hill, New York.

Gencer, R.T., Demir, C. and Aycan, A. (2008). Kayak merkezlerindeki spor turistlerinin hizmet kalitesi algilarını etkileyen değişkenler. Ege Akademik Bakış, 8(2), 437-450.

Göksel, A.G. (2012). Su sporları hizmeti sunan işletmelerde müşteri memnuniyetinin araştırnlması. (yüksek lisans tezi). Sttkı Koçman Üniversitesi Sosyal Bilimler Enstitüsü, Muğla.

Güdül, N. (2008). Fitness salonlarna giden bireylerin beklentileri. (yüksek lisans tezi). Afyonkarahisar Kocatepe Üniversitesi Sağlık Bilimleri Enstitüsü, Afyonkarahisar.

Kalaycı, Ş. (2010). SPSS uygulamalı çok değişkenli istatistik teknikleri. (5. Baskı). Ankara: Asil Yayın Dağıtım.

Karasar, N. (2000). Bilimsel araştırma yöntemi. Ankara: Nobel Yayın Dağı̆tım.

Karasar, N. (2009). Bilimsel araştırma yöntemi. Ankara: Nobel Yayınları.

Kim, D. and Kim, S. (1995). QUESC: An instrument for assessing the service quality of sport centers in Korea. Journal of Sport Management, 9, 208-220.

Kline, R. B. (2016). Principles and practice of structural equation modeling (4th $\mathrm{ed}$.). Guilford Publications, New York.

Lapa, T.Y. and Baştaç, E. (2012). Antalya' da fitness merkezlerine devam eden bireylerin yaş, cinsiyet ve eğitimlerine göre bu merkezlere yönelik hizmet kalitesi değerlendirmelerinin incelenmesi. Pamukkale Journal of Sport Sciences, 3(1), 42-52.

Liu, Y. D., Taylor, P. and Shibli, S. (2009). Measuring customer service quality of English public sport facilities. International Journal of Sport Management and Marketing, 6(3), 229-252.

McDonald, M. A., Sutton, W.A. and Milne, G.R. (1995). Teamqual: Measuring service quality in professional team sports. Sport Marketing Quarterly, 4(2), 9-15.

Memiş, U.A. (2002). Spor tesislerinde müşteri memnuniyeti. (yüksek lisans tezi). Gazi Üniversitesi Sağlık Bilimleri Enstitüsü, Ankara.

Memiş, U.A. ve Ekenci, G. (2007). Spor merkezlerinde müşteri memnuniyeti (Ankara ili örneği). Gazi Beden Ĕ̆itimi ve Spor Bilimleri Dergisi, 12(1), 33-48.

Özdamar, K. (1999). SPSS ile biyoistatistik. (3. Baskı), Kaan Kitabevi.

Öztürk, H., Adiloğulları, İ. ve Mungan Ay, S. (2011). Sağlıklı yaşam ve spor merkezi müşterilerinin tatmin düzeylerinin bazı demografik değişkenler açısından incelenmesi. CBÜ Beden Ĕ̆itimi ve Spor Bilimleri Dergisi, 6(2), 31-38. 
Sabırlı, T.N. (2018). Belediyelerin sunduğu rekreasyonel spor hizmetlerinden yararlanan tüketicilerin hizmet kalitesi ve tatmin düzeylerinin incelenmesi. (doktora tezi). Gazi Üniversitesi Sağlık Bilimleri Enstitüsü, Ankara.

Saraç, Y. (2018). Kamuya ait spor işletmelerinden hizmet alan bireylerin memnuniyetini etkileyen faktörlerin incelenmesi (Beylikdüzü Belediyesi örneği). (yüksek lisans tezi). İstanbul Gelişim Üniversitesi Sosyal Bilimler Enstitüsü, İstanbul.

Saygın, Ö. (2015). Long-term walking exercise may affect some physical functions in the elderly. Ethno Medicine, 9(3), 379-384.

Sevilmiş, A. (2015). Hizmet odaklı spor işletmelerinde dış müşteri memnuniyetini etkileyen faktörlerin belirlenmesi. (yüksek lisans tezi). Selçuk Üniversitesi Sağlık Bilimleri Enstitüsü, Konya.

Süllüoğlu, O. (2018). Fitness Center'lardaki hizmet kalitesinin müşteri memnuniyeti üzerindeki etkisi. (yüksek lisans tezi). Bahçeşehir Üniversitesi Sosyal Bilimler Enstitüsü, İstanbul.

Şahin, R. (2018). Fitness merkezlerinde algllanan hizmet kalitesi, algzlanan değer, müşteri memnuniyeti ve davranışsal niyetler arasındaki ilişkiler. (yüksek lisans tezi). Ege Üniversitesi Sağlık Bilimleri Enstitüsü, İzmir.

Şimşek, K.Y. (2016). Quality perception of the 2012 world indoor athletics championships, Journal of Human Kinetics, 54, 181-194.

Şimşek, O. F. (2007). Yapısal eşitlik modellemesine giriş, temel ilkeler ve lisrel uygulamaları. Ankara: Ekinoks.

Terekli, M.S., Katırcı, H., Heper, E. ve Erkan, M. (2000). Sporda yönetim anlayışı ve çağdaş spor yönetimi, H.Ü. spor bilimleri ve teknolojisi. Spor Bilimleri Derneği Bildiri Özetleri, 3-5 Kasım, Ankara.

Theodorakis, N., Alexandris, K., Rodrigues, P.M.M. and Sarmento, P.J. (2004). Measuring customer satisfaction in the context of health clubs in portugal. International Sports Journal, 8, 44-53.

Uslu, S., Polat, E. ve Üzüm, H. (2018). Özel sektör ve üniversite spor-fitness merkezlerinin algılanan hizmet kalitesi düzeylerinin bazı değişkenlere göre incelenmesi, 3. Uluslararası Avrasya Spor Eğitim ve Toplum Kongresi Tam Metin Kitabı, Mardin.

Üzüm, H., Yeşildağ, B., Karlı, Ü., Ünlü, H., Parlar, F.M., Çokpartal, C. ve Tekin, N. (2016). Kamu ve özel spor merkezleri müşterilerinin hizmet kalitesi algılarınin incelenmesi, AIB̈̈̈ Sosyal Bilimler Enstitüsü Dergisi, 16(3), 167-180.

Yıldırım, M. (2018). Spor tesislerinden yararlanan kişilerin tesislerden memnuniyet düzeylerinin belirlenmesi (Eskişehir Osmangazi Üniversitesi örneği). Akdeniz Eğitim Araştırmalarn Dergisi, 12(25), 342-360. 
Yıldız, S. M., Duyan, M. ve Günel, İ. (2018). Hizmet kalitesinin müşteri memnuniyeti üzerine etkisi: Fitness merkezlerinde ampirik bir uygulama. Spor Bilimleri Araştırmaları Dergisi, 3(1), 1-8.

Yıldız, S.M. (2008). Spor hizmetleri kalitesini değerlendirmede kullanulabilecek hizmet kalitesi modelleri ve ölçüm araçları. Gazi Beden Eğitimi ve Spor Bilimleri Dergisi, 8(3), 38-48.

Ylldız, S.M. (2009). Service quality models in participant sports services. Ege Academic Review, 9(4), 1213-1224.

Yıldız, S.M., Tüfekçi, Ö. (2010). Fitness merkezi müşterilerinin hizmet kalitesine yönelik beklenti ve algilarının değerlendirilmesi. Balkesir Üniversitesi Sosyal Bilimler Enstitüsü Dergisi, 14(24), 1-11.

Yüzgenç, A.A. (2010). Yerel yönetimlerin sunduğu spor hizmetlerinde hizmet kalitesi. (yayınlanmamış yüksek lisans tezi). Gazi Üniversitesi, Ankara.

Yüzgenç, A.A. ve Özgül, S.A. (2014). Yerel yönetimlerin sunduğu spor hizmetlerinde hizmet kalitesi (Gençlik merkezleri ve aile yaşam gençlik merkezleri örneği). Hacettepe Spor Bilimleri Dergisi, 25(2), 79-93.

\section{Kaynakça Bilgisi / Citation Information}

Uslu, S. ve Yıldırım, M. (2021). Spor İşletmelerinde Müşteri Memnuniyetinin Bazı Değişkenlere Göre İncelenmesi. OPUS-Uluslararası Toplum Araştırmaları Dergisi, 18(Yönetim ve Organizasyon Özel Say1s1), xxxx-xxxx. DOI: 10.26466/opus.899522 